\title{
The pianosa contourite depositional system (northern Tyrrhenian sea): drift morphology and plio-quaternary stratigraphic evolution
}

\author{
Miramontes Garcia Elda ${ }^{1,{ }^{*}}$, Cattaneo Antonio ${ }^{1}$, Jouet Gwenael ${ }^{1}$, Théreau Estelle ${ }^{1}$, Thomas Yannick ${ }^{1}$, \\ Rovere Mickael ${ }^{2}$, Cauquil E. ${ }^{3}$, Trincardi F. ${ }^{2}$ \\ ${ }^{1}$ IFREMER, Géosciences Marines-EDROME, Centre de Brest, BP70, CS10070, 29280 Plouzané, \\ France \\ 2 ISMAR-CNR, Via P. Gobetti 101, 40129, Bologna, Italy \\ ${ }^{3}$ TOTAL SA, La Défense, France \\ *Corresponding author : Elda Miramontes Garcia, email address : elda.miramontes.garcia@ifremer.fr
}

\begin{abstract}
:
The Pianosa Contourite Depositional System (CDS) is located in the Corsica Trough (Northern Tyrrhenian Sea), a confined basin dominated by mass transport and contour currents in the eastern flank and by turbidity currents in the western flank. The morphologic and stratigraphic characterisation of the Pianosa CDS is based on multibeam bathymetry, seismic reflection data (multi-channel high resolution mini GI gun, single-channel sparker and CHIRP), sediment cores and ADCP data. The Pianosa CDS is located at shallow to intermediate water depths (170 to $850 \mathrm{~m}$ water depth) and is formed under the influence of the Levantine Intermediate Water (LIW). It is $120 \mathrm{~km}$ long, has a maximum width of $10 \mathrm{~km}$ and is composed of different types of muddy sediment drifts: plastered drift, separated mounded drift, sigmoid drift and multicrested drift. The reduced tectonic activity in the Corsica Trough since the early Pliocene permits to recover a sedimentary record of the contourite depositional system that is only influenced by climate fluctuations. Contourites started to develop in the Middle-Late Pliocene, but their growth was enhanced since the Middle Pleistocene Transition (0.7-0.9 Ma). Although the general circulation of the LIW, flowing northwards in the Corsica Trough, remained active all along the history of the system, contourite drift formation changed, controlled by sediment influx and bottom current velocity. During periods of sea level fall, fast bottom currents often eroded the drift crest in the middle and upper slope. At that time the proximity of the coast to the shelf edge favoured the formation of bioclastic sand deposits winnowed by bottom currents. Higher sediment accumulation of mud in the drifts occurred during periods of fast bottom currents and high sediment availability (i.e. high activity of turbidity currents), coincident with periods of sea level low-stands. Condensed sections were formed during sea level high-stands, when bottom currents were more sluggish and the turbidite system was disconnected, resulting in a lower sediment influx.
\end{abstract}




\section{Highlights}

- The development of contourites was enhanced after the Middle Pleistocene Transition Contourites morphology is controlled by inherited physiography and tectonic features The internal structure and stratigraphy is dictacted by climatic fluctuation - The drifts are muddy with coarser layers deposited during sea level falls $>$ Contourite drifts present higher accumulation rates during sea level low-stands

Keywords : Sediment drift, Bottom current, Levantine intermediate water, Modified Atlantic water, Mediterranean sea, Sea level

\section{Introduction}

Contour currents are strictly defined as bottom currents flowing alongslope, parallel to a bathymetric contour, and driven by the thermohaline circulation or by the wind (Rebesco et al., 2008). The sediment deposits related to persistent contour currents, named contourites, were first recognised in deep sea environments (Heezen and Hollister, 1964). Numerous cases of contourite drifts controlled by the activity of long-lasting bottom currents have been later identified on the continental shelves (Harris and Beaman, 2003; Harris et al., 1999; Vandorpe et al., 2011) and the upper slope (Marani et al., 1993; Viana et al., 1998; Verdicchio and Trincardi, 2008a) in oceanic settings and along Mediterranean margins. Contourites in the Mediterranean Sea are typically of smaller size compared to drifts found in oceanic settings (Verdicchio and Trincardi, 2008b) and tend to be confined in settings constrained by local morphology such as straits or channels (Pellegrini et al., 2015 and references therein). 
Shallow and intermediate depth contourites are more directly affected by sea level fluctuations, since during sea level low-stands, even if they remain in submerged conditions, the sediment flux from the continental shelf is usually enhanced and downslope transport is more frequent. In addition, the upper continental slope may be more influenced by winddriven currents and the depth range of the superficial and intermediate water masses may change and thus the current regime affecting the seafloor.

Mixed turbidite-contourite systems are common along continental margins where contour currents rework and/or redistribute gravity deposits (Mulder et al., 2008). The interaction between downslope gravity currents and alongslope contour currents is often recognised when both processes take place along the same margin (Rebesco et al., 2002; Hernández-Molina et al., 2006; Marches et al., 2010; Brackenridge et al., 2013). In the Corsica Trough, turbidity and contouritic processes have occurred in opposite margins of the basin. This physical separation of along- and downslope processes avoids problems associated with the identification and differentiation of sediment bodies related to contour or turbidity currents, and permits to better constrain the influence of the activity of turbidity currents on the development of contourites.

The purpose of this study is to present an accurate morphologic and stratigraphic characterisation of the contourite depositional system located on the eastern flank of the Corsica Trough, named here the Pianosa Contourite Depositional System (CDS). Thanks to the confined setting and the available stratigraphic control, the Pianosa CDS provides a unique opportunity to achieve a high resolution reconstruction of the spatial and chronological contourite evolution and to infer their relationship to the activity of the turbidite system and sea level fluctuations.

\section{Regional setting}




\subsection{Geology and morphology}

The Corsica Trough is a narrow basin located in the Northern Tyrrhenian Sea (Fig. 1), flanked by the Corsica Island to the west and by the Pianosa Ridge and the Tuscan Shelf to the east (Fig. 2). It is a N-S trending basin, about $100 \mathrm{~km}$ long and 10-35 km wide at depth of the shelf edge. This basin connects the Ligurian and Tyrrhenian Seas. It has a maximum depth of 880 $\mathrm{m}$ in the southern part, becoming shallower towards the north. The narrowest and shallowest zone is found offshore the Capraia Island, where the Tuscan and Corsican continental shelves are separated by the Corsica Sill, that is $9.5 \mathrm{~km}$ wide between opposite shelf edges (Fig. 2).

The Corsica Trough developed during the opening of the Northern Tyrrhenian Sea, between the late Burdigalian and Langhian (Zitellini et al., 1986), resulting in the formation of a half graben (Pascucci, 2002). The Pianosa Ridge corresponds to a tilted block of the half graben, with the master fault located on the Corsican side of the basin (Pascucci, 2002) and separates the Corsica Trough from the Tuscan Shelf. Several N-S and NW-SE trending basins can be found in the Tuscan Shelf (Pascucci et al., 2007), trapping a great part of the sediment from Italy (Roveri, 2002). They developed on a thrust substrate locally dissected by normal faults (Bartole, 1995).

The asymmetry of the Corsica Trough is the result of tectonic processes and is still evident at the present seafloor (Fig. 2). The western flank of the basin has a gentle slope (mean values between $2^{\circ}$ and $3^{\circ}$ ), while the eastern flank, formed by the Pianosa Ridge, has steeper slopes (between $3^{\circ}$ and $10^{\circ}$, reaching $20^{\circ}$ locally). The western part of the Corsica Trough is dominated by downslope gravity-driven depositional processes that resulted in the formation of the Golo turbidite network (Fig. 2; Gervais et al., 2004; Gervais et al., 2006; Deptuck et al., 2008; Calves et al., 2013). On the other side, the Pianosa Ridge is characterised by both alongslope processes, resulting in contourite drifts (Marani et al., 1993; Roveri, 2002; 
Cattaneo et al., 2014), and downslope mass-wasting processes (Cattaneo et al., 2014; Miramontes et al., 2016).

\subsection{Oceanography}

The limited depth of the Corsica Trough $(\max .880 \mathrm{~m})$ does not allow the transit of the Mediterranean Deep Water, being the Levantine Intermediate Water (LIW) the only water mass in contact with the seafloor. The Western Intermediate Water formed in the LiguroProvençal sub-basin is not present in the Tyrrhenian Sea. Therefore, the LIW is in general located just below the Modified Atlantic Water (MAW) (Millot, 2013). The MAW is found at water depths ranging from 0 to $200 \mathrm{~m}$ (Astraldi and Gasparini, 1992; La Violette, 1994; Millot, 1999; Toucanne et al., 2012). The LIW is formed in the Rhodes cyclonic gyre in the NW of the Levantine Basin (Fig. 1) by a process of evaporation during the summer, resulting in a warm and salty surface water mass, and a later winter cooling that increases its density. As a consequence, the water sinks inside the Rhodes cyclone during February and March (Lascaratos et al., 1999). The LIW formation presents interannual variability: the formation area is enlarged during very cold winters, covering the whole north Levantine Basin (Lascaratos et al., 1999). After its formation, the LIW flows westwards through the Strait of Sicily, then it continues northwards in the Tyrrhenian Sea. A branch of the LIW keeps the same direction crossing the Corsica Trough, while another brach turns to the south and flows along eastern Sardinia (Fig. 1; Millot and Taupier-Letage, 2005).

The circulation along the eastern part of the Corsica Trough is characterised by northward flowing currents that change significantly with seasons, being stronger during the cold seasons (reaching 10-40 $\mathrm{cm} \cdot \mathrm{s}^{-1}$ from late autumn to early spring) (Astraldi and Gasparini, 1992; Vignudelli et al., 1999) and resulting in a higher water transport through the Corsica Trough during this period (Vignudelli et al., 2000). The seasonal variability is in part caused 
by a climatological steric difference in sea level between the Ligurian and the Tyrrhenian Seas because of the formation of colder and saltier water masses in the Ligurian Sea during the winter (Vignudelli et al., 2000). These changes in circulation are related to large-scale atmospheric patterns, such as the North Atlantic Oscillation (Vignudelli et al., 1999). Similar processes have likely occurred in the past. During cold periods bottom water masses were better ventilated (Cacho et al., 2000; Minto'o et al., 2015) and faster (Toucanne et al., 2012) in the Mediterranean Sea. More arid and cold climatic conditions during cold intervals could favour the production of denser LIW (Cacho et al., 2000).

\section{Materials and methods}

The present study is based on the analysis of seismic reflection and sedimentological data acquired in the Corsica Trough since 1990 (Marani et al., 1993; Roveri, 2002; Gervais et al., 2004; Deptuck et al., 2008; Toucanne et al., 2012; Calves et al., 2013; Angue Minto'o, 2014; Toucanne et al., in press). The multibeam bathymetry from the Corsica Trough was acquired during the SIGOLO survey in 2008 (Calves et al., 2013) and completed with the zone of the Pianosa Ridge during surveys PRISME2-PAPRICA and PRISME3 carried out by IFREMER in 2013 onboard the R/V Atalante and the R/V Pourquoi pas?, respectively. The outer bathymetric data were retrieved from the EMODnet Bathymetry compilation (http://portal.emodnet-bathymetry.eu/). The seismic data used for the study are 2D seismic reflection profiles: single-channel $1 \mathrm{~kJ}$ sparker $(50-60 \mathrm{~Hz})$ profiles collected during cruises ET91 (N/O Bannock), ET93 and ET95 (N/O Urania) carried out by the former Istituto di Geologia Marina of Bologna of the Italian National Research Council (CNR), now ISMARCNR (Roveri, 2002); CHIRP (Compressed High Intensity Radar Pulse, 1800-5300 Hz) profiles and 72-channel high-resolution profiles sourced by a mini GI gun $(50-250 \mathrm{~Hz})$ were acquired in 2013 during cruises PRISME2-PAPRICA and PRISME3 (Figs. 2 and 3). Seismic data from surveys ET91 and ET95 were interpreted from analogical profiles and used for the 
mapping of the contourites. Current velocity was acquired with the hull-mounted Acoustic Doppler Current Profiler (ADCP) OS38 of R/V Atalante during the cruise PRISME2PAPRICA in August 2013. The data were processed with the CASCADE V6.1 software developed by IFREMER. Tide corrections and a linear filters were applied.

The seven Calypso piston cores used for this study were collected during the cruise PRISME3 along the Pianosa Ridge in 2013. P-wave velocity and gamma-density were measured on whole core sections using a Geotek Multi-Sensor Core logger (MSCL) at IFREMER laboratories. The bulk sediment semi-quantitative geochemical composition was measured with an Avaatech X-ray fluorescence (XRF) core scanner at IFREMER on split cores, except on intervals of coarse sediment, that were skipped due to methodological constraints. Cores PSM3-CS009 and PSM3-CS011 were sampled for grain size analysis with variable spacing ranging from $10 \mathrm{~cm}$ (in the homogeneous muddy facies) to $2 \mathrm{~cm}$ (in the sandy areas and mudsand transitions). Grain size measurements were performed using a Coulter LS200 laser microgranulometer with no chemical pre-treatment of the bulk sediment. Further grain size measurements were performed on the carbonate-free fraction of the upper $6.85 \mathrm{~m}$ of core PSM3-CS011 using a Malvern Mastersizer 3000 laser microgranulometer. The sortable silt (SS) mean size (the mean value of the $10-63 \mu \mathrm{m}$ grain size fraction) was used as a proxy for palaeobottom flow speed (McCave and Hall, 2006; McCave et al., 1995).

Radiocarbon dating measurements were performed on bulk planktonic foraminifera and carried out by the Beta Analytic and the Poznan radiocarbon laboratories (Table 1). Radiocarbon ages were corrected for a marine reservoir effect of 400 years and calibrated using Calib 7.0.2 radiocarbon calibration software and the IntCal13 calibration curve (Reimer et al., 2013). Stable isotope (oxygen) measurements were carried out on samples from core PSM3-CS011 using specimens of benthic foraminifera (Uvigerina peregrina and Uvigerina mediterranea) from the size fraction higher than $150 \mu \mathrm{m}$. Isotope analyses were done at the 
laboratories of the Leibniz Institute of Marine Sciences of the University of Kiel. A correction factor of $-0.25 \%$ for $\delta^{18} \mathrm{O}$ was applied to the isotope values from Uvigerina mediterranea to take into account the common differences in isotope values recorded between $U$. peregrina and $U$. mediterranea related to their different vital and habitat preferences (Fontanier et al., 2006; Schmiedl et al., 2004). The $\delta^{18} \mathrm{O}$ curve of borehole GDEC4-2 (western slope of the Corsica Trough; Fig. 3; Ange Minto'o, 2014; Toucanne et al., in press) was used as a reference for the construction of the age model with the $\delta^{18} \mathrm{O}$ values of core PSM3-CS011 (eastern slope of the Corsica Trough, Pianosa Ridge). Cores PSM3-CS012 and PSM3-CS009 were correlated with PSM3-CS011 using the $\mathrm{Ca} / \mathrm{Fe}$ ratio obtained from the XRF. The chronology is supported by multiple radiocarbon dates (Table 1) and by seismic correlation with borehole GDEC4-2. Carbonates recovered at the bottom of PSM3-CS015 (Fig. 3) were dated by SEDISOR using Strontium isotopes.

The depth below the seafloor of the cores was corrected using the software CINEMA $^{2}$ that measures the space for sampling during the penetration between the bottom of the piston and the bottom of the core catcher and permits to know the in situ depth that corresponds to the position in the core (Woerther et al., 2012). Corrected depths were used to estimate sedimentation rates.

Compression indexes obtained from oedometer tests, carried out on cores PSM3-CS009 and PSM3-C012, were used to correct the effect of compaction on the sediment thickness and thus to calculate sedimentation rates, by applying the compressibility equation that links the void ratio $(e)$ with the vertical effective stress $\left(\sigma^{\prime}{ }_{v}\right)$ (Garziglia, 2010; Lambe and Withman, 1979; Nygard et al., 2004):

$$
e=e_{0}-\lambda \cdot \ln \left(\frac{\sigma_{\mathrm{v}}}{\sigma^{\prime} \mathrm{v} 0}\right)
$$


where $e_{0}$ is a reference void ratio at a reference vertical effective stress $\sigma^{\prime}{ }_{v 0}$ of $1 \mathrm{kPa}$ and $\lambda$ is the compression index. The $e-\ln \left(\sigma_{v}^{\prime}\right)$ plots obtained from the oedometer test provide the values of $e_{0}$ as the intersection of the virgin compression line and the reference value $\sigma^{\prime}{ }_{v}=1$ $\mathrm{kPa}$. The compression index $(\lambda)$ is the slope of this line. The values used for core PSM3CS009 are $\lambda=0.180$ and $e_{0}=1.921$; and for core PSM3-CS012 $\lambda=0.204$ and $e_{0}=2.111$. They correspond to the mean $\lambda$ and $e_{0}$ values obtained from 5 oedomenter tests on samples from core PSM3-CS012 and 4 oedometer tests on samples of PSM3-CS009 located in between 2 and 11 mbsf. Decompaction in core PSM3-CS011 was carried out using $\lambda$ and $e_{0}$ values obtained from core PSM3-CS009.

The change in thickness $(\Delta h)$ of a sediment layer of thickness $h$, created by the increment of the lithostatic stress, depends directly on the change in void ratio $(\Delta e)$, according to:

$\frac{\Delta h}{h}=\frac{\Delta e}{1+e_{0}}=-\frac{\lambda}{1+e_{0}} \ln \left(\frac{\sigma_{\mathrm{v}}^{\prime}}{\sigma^{\prime}{ }_{\mathrm{v} 0}}\right)$

Then, the decompacted thickness $h_{d}$ can be calculated following the equation:

$h_{d}=\mathrm{h}\left[1+\frac{\lambda}{1+e_{0}} \ln \left(\frac{\sigma^{\prime}{ }_{\mathrm{v}}}{\sigma^{\prime}{ } 0}\right)\right]$

\section{Results}

\subsection{Evidences of present-day bottom-current activity}

Current velocity obtained from hull-mounted ADCP shows two main zones with northward currents and higher velocities $\left(25-30 \mathrm{~cm} \cdot \mathrm{s}^{-1}\right)$, found at $50-200 \mathrm{~m}$ and at $700-850 \mathrm{~m}$ in the eastern part of the basin (Fig. 4A). The whole water column flows northwards in the eastern part of the Corsica Trough at about $10 \mathrm{~cm} \cdot \mathrm{s}^{-1}$, while the central-western part of the basin has a preferential velocity of about $5 \mathrm{~cm} \cdot \mathrm{s}^{-1}$ towards the south, with maximum values of $10 \mathrm{~cm} \cdot \mathrm{s}^{-1}$ at 100-200 m water depth (Fig. 4B). 
The coupling of ADCP data and the seafloor reflections provides a better understanding of how currents influence the seafloor morphology. Figure 4A shows a faster $\left(25-30 \mathrm{~cm} \cdot \mathrm{s}^{-1}\right)$ pathway of the LIW in northern direction at about $800 \mathrm{~m}$ water depth (w.d.) that decreases in velocity towards the north, at the place where the separated, elongated, mounded drift starts to develop. Higher velocities are found at the lower slope, at the bottom of the Pianosa Slump scar, where the present-day seafloor gradient is $13^{\circ}$ (Fig. 4B).

The LIW pathway is strongly affected by the presence of a seafloor depression, that we define as the Elba Canyon (Fig. 2), in the short-term by inducing an upwelling to the north of the canyon (Fig. 5) and in the long-term by forming sigmoid drifts at the north of the canyon (Fig. 6B). Although the multi-channel high resolution mini GI seismic data were acquired and calibrated to image the sediment below the seabed, some reflections are apparent in the upper water column (Fig. 5). The horizontal reflections located at 120-150 m w.d. are interpreted as the mixing zone between the Modified Atlantic Water (MAW) and the Levantine Intermediate Water. Other minor changes in salinity and/or temperature of the Levantine Intermediate Water may have formed the deeper reflections found between 225 and $270 \mathrm{~m}$ w.d. ( Fig. 5).

\section{2. Distribution and morphology of the Pianosa Contourite Depositional System}

The Pianosa CDS is $120 \mathrm{~km}$ long and has a maximum width of $10 \mathrm{~km}$, extending along the Pianosa Ridge, also known as Elba Ridge (Roveri, 2002) or Elba-Pianosa Ridge (Pascucci et al., 1999), from the southernmost part (west of Montecristo Island; Fig. 2) to the north of the Corsica Sill, that connects the Ligurian and the Tyrrhenian Seas at the north of the Capraia Island (Fig. 2). The drift size and morphology present remarkable changes along the system due to the variations in depth and physiography of the basin and the Pianosa Ridge. For a 
better understanding, the system has been divided in seven zones (zone 1 at the south and zone 7 at the north; Fig. 2).

Two separated mounded drifts have been identified in the southernmost part of the CDS (zone 1; Fig. 2). An escarpment generates a local acceleration of bottom currents, maintaining an abraded surface where the Messinian surface outcrops at the seafloor, and forming adjacent contourite drifts (Fig. 7). North of this zone, a plastered drift is found in the continental slope between 230 and $700 \mathrm{~m}$ w.d., bounded in the upper part by faster bottom currents formed at the interphase between the MAW and the LIW (Fig. 4B). The southern part of the plastered drift was affected by multiple mass-wasting processes that formed scars on the slopes and mass transport deposits on the basin (Figs. 4B and 6A). A small mounded drift was formed at the bottom of the scar of the Pianosa Slump, related to faster bottom currents at the foot of the slope (Fig. 4B).

Faster bottom currents present along the lower slope at about 600-650 m depth (Fig. 4B) are coincident with the location of a deep moat (up to $56 \mathrm{~m}$ deep) in zone 2 (Fig. 2), that creates a corridor with steeper slopes, up to $15^{\circ}$ (Fig. 8). West of the moat, an elongated separated drift is formed, with the western limit marked by an inflexion in the slope: turbidites and hemipelagites dip eastwards, while contourite drifts dip westwards (Fig. 8). Offshore the Pianosa Island (zone 2) the Pianosa Ridge is retreated towards the east, forming a bulge on the slope (Fig. 6A). This morphological structure induced a change in the LIW pathway. While the mentioned deeper LIW branch continues northwards, another branch of the current flows at about $400 \mathrm{~m}$ depth contouring the slope edge and forming sigmoid moats and sigmoid separated mounded drifts (Figs. 6A and 8).

North of the bulge in the Pianosa Ridge (zone 3; Fig. 2) the continental slope is relatively steep with slope values between $8^{\circ}$ and $10^{\circ}$. An abraded surface extends from the bottom of 
the prograding shelf edge prism at $225 \mathrm{~m}$ depth, that was formed during the last sea level lowstand, to the mounded drift, until $560 \mathrm{~m}$ water depth (Figs. 6A and 9). In this zone the moat is flat and the crest is not very well developed. The separated elongated mounded drift presents multiple undulations and a pockmark field (Figs. 6A and 9). Slightly to the north, the same contourite drift has a more developed mounded shape at the crest next to the moat, which is about $1 \mathrm{~km}$ wide and was originated by an obstacle created by a buried mass transport deposit (Fig. 10).

North of the Pianosa Island (zone 4; Fig. 2) the slope becomes gentler $\left(2-6^{\circ}\right)$ and contourite drifts develop from 650 to $200 \mathrm{~m}$ water depth (Figs. 11 and 12). The deeper LIW branch flows in northeast direction until it converges with the shallowest branch that flows northwards parallel to the ridge (Fig. 2). As a result, and probably also due to the interaction with the Elba Canyon, multiple branches with north-east direction are formed, resulting in the deposition of multicrested drifts (Figs. 6B, 11 and 12).

The Elba Canyon is located offshore the Elba Island and it is the only canyon that crosses the Pianosa Ridge. Neither channel-levee systems nor turbidite lobes have been found associated with this canyon, and a low-stand shelf edge prism was deposited on the top of the canyon head (Fig. 11). Bottom currents have modelled its morphology in three different ways:

1: A contourite drift extends into the inner southern flank of the canyon (Fig. 13).

2: Downslope bottom currents through the canyon are accelerated towards the north, eroding the northern flank and forming an asymmetric canyon. The slope in the northern eroded flank is steeper (up to $20^{\circ}$ ) than in the southern flank, that is dominated by drift deposits (up to $15^{\circ}$ ) (Fig. 13). 
3: Downslope bottom currents are deflected towards the north when they flow out of the canyon toe, creating an abrupt transition with high seafloor gradients (up to $15^{\circ}$ ) between the basin and the lower slope (Figs. 6B and 11).

In zone 5 (Fig. 2), the LIW pathway is affected by the presence of the canyon and it is separated in two branches (Fig. 2). The first branch continues flowing northwards at about $650 \mathrm{~m}$ w.d. The second shallowest branch is deflected towards the east, upwelling until about 150 m w.d. (Figs. 5 and 6B), where it becomes stabilised and continues flowing northwards, constrained by the steep morphology of the continental slope. The shallowest branch forms a sigmoid separated mounded drift similar to the drift located at the south of the Pianosa Island (zone 2). Northwards, these two LIW pathways run parallel, the shallowest one forms a 30-mdeep moat located parallel to the ridge at about $350 \mathrm{~m}$ w.d.; and the deepest pathway forms a 35-m-deep moat at $500 \mathrm{~m}$ w.d. (Fig. 14). These mounded drifts become flatter towards the north, at the same time that the basin becomes shallower and narrower, favouring erosion and non-deposition (Fig. 15).

The northernmost part of the system is characterised by patchy mounded drifts related to obstacles. North of the Corsica Sill, the basin opens in a funnel shape. Consequently, the LIW likely decelerates, favouring the sediment deposition and the formation of a drift (zone 6; Fig. 2). Finally, in the middle of the funnel-shaped basin (zone 7), a contourite drift is formed, associated with a mounded elevation (Fig. 2).

\subsection{Stratigraphy of the Pianosa Contourite Depositional System}

\subsubsection{Seismic stratigraphy and age model}

The Corsica Trough entered in a rifting phase during the Middle Miocene (Zitellini et al., 1986). Horizon $Z$ (name used by Zitellini et al., 1986) corresponds to the seismic reflection that marks the lower boundary of the syn-rift deposits (Figs. 8, 9; Zitellini et al., 1986). 
Reflection Y (name used by Zitellini et al., 1986) is the erosional surface formed during the Messinian salinity crisis (Table 2). It corresponds to a very high amplitude reflection that marks a strong increase in sound velocity, since it separates the Plio-Quaternary sediment from the Miocene carbonates. Core PSM3-CS015 sampled the carbonates that form this surface in the Pianosa Ridge (Fig. 3), dated at 9.25 $\pm 0.27 \mathrm{Myr}$ (Tortonian age, Late Miocene) through Strontium isotopic stratigraphy. This result suggests that no Messinian material is preserved in the Pianosa Ridge. Reflection X (name used by Zitellini et al., 1986) is the base of the post-rift deposits, of Middle Pliocene age (Table 2; Zitellini et al., 1986). Unit Y/X was deposited during the early Pliocene and it is mainly located in the deeper part of the basin. It usually onlaps the flanks of the basin, but in some zones it forms a thin layer concordant to the lower slope (Figs. 8 and 9).

The sediment deposited in the Corsica Trough from the Middle Pliocene (reflection X) to the present-day, is composed of 7 main units: U1, U2, U3, U4, U5, U6 and U7 (Figs. 8 and 9). Unit 1 is bounded between seismic reflection $X$ (Middle Pliocene) and D1. The seismic discontinuity D1 is proposed to be related to the Middle Pleistocene Transition (MPT, 700900 kyr) by analogy with the Quaternary stratigraphic pattern suggested by HernándezMolina et al. (2002) for the Gulf of Cadiz and the Alboran Sea (Table 2). Reflections in unit 1 onlap the lower part of the continental slope and are concordant to the middle slope. The upper boundary of unit 1 is the erosional surface D1. This regional erosion removed most of the sediment deposited on the middle slope, forming erosional truncations on the easternmost part of unit 1 (Figs. 7, 8 and 9). Mounded reflections can be found in unit 1, evidencing the presence of mounded drifts in all the system, more developed in the vicinity of the Elba Canyon (Fig. 12). Unit 2 is bounded by erosional seismic reflection D1 and D2, both characterised by being of high amplitude (Figs. 8, 9, 12, 16C and 17B). D2 is deeper than the 
bottom of borehole GDEC4-2 (western side of the Corsica Trough) that was dated at $550 \mathrm{kyr}$ BP.

Units 3 to 7 are separated by seismic reflections of high amplitude that correspond to coarser sediment layers (Figs. 8, 9, 12 and 17). All the units present similar characteristics: they alternate packages of low amplitude reflections with packages of high amplitude reflections (Fig. 9). Unit 7 is the most recent one, it is characterised by low amplitude reflections that follow the same morphology as the previous units, but it drapes the shallowest moat in zones 2 and 3, as well as part of the middle slope, thinning upslope (Figs. 8, 9 and 16C). Seismic and oxygen isotope correlation with borehole GDEC4-2 allowed the more precise chronology of units 3 to 7 (Fig. 17A). Unit 3 extends until MIS 10, unit 4 from MIS 10 to MIS 6, unit 5 from MIS 6 to MIS 4, unit 6 from MIS 4 to MIS 2 (30 kyr) and unit 7 from 30 kyr to the present (Table 2).

Sedimentation rates (SR) were calculated for unit 7 in contourite drifts of zone 2 (Fig. 18). The core depths used for the estimation of sedimentation rates were corrected for coring perturbations (Woerther et al., 2012) and mechanical compaction effects. SR on the crest of the mounded contourite drift in the middle slope from core PSM3-CS009 (Figs. 6, 14 and 15) resulted in a mean SR value corrected for compaction and core sampling perturbations of 13 $\mathrm{cm} \cdot \mathrm{kyr}^{-1}$ for the last $12 \mathrm{kyr}$. (non-corrected SR would be $9.5 \mathrm{~cm} \cdot \mathrm{kyr}^{-1}$ ) and $81 \mathrm{~cm} \cdot \mathrm{kyr}^{-1}$ between 12 and $30 \mathrm{kyr}$ (non-corrected SR is $63 \mathrm{~cm} \cdot \mathrm{kyr}^{-1}$ ) (Fig. 18). Core PSM3-CS012 is located in a deeper zone of the contourite, farther from the moat, where sediment accumulation slightly lower, with mean corrected SR values of $11 \mathrm{~cm} \cdot \mathrm{kyr}^{-1}$ for the last $12 \mathrm{kyr}$ BP (non-corrected SR would be $6 \mathrm{~cm} \cdot \mathrm{kyr}^{-1}$ ) and $70 \mathrm{~cm} \cdot \mathrm{kyr}^{-1}$ between 12 and $30 \mathrm{kyr} \mathrm{BP}$ (noncorrected SR is $47 \mathrm{~cm} \cdot \mathrm{kyr}^{-1}$ ). Core PSM3-CS011 shows a similar pattern in sedimentation rates, with lower values during the last $17.3 \mathrm{kyr}\left(9 \mathrm{~cm} \cdot \mathrm{kyr}^{-1}, 6 \mathrm{~cm} \cdot \mathrm{kyr}^{-1}\right.$ non-corrected $)$ and higher SR between 17.3 and $26.7 \mathrm{kyr}\left(88-111 \mathrm{~cm} \cdot \mathrm{kyr}^{-1}, 61-68 \mathrm{~cm} \cdot \mathrm{kyr}^{-1}\right.$ non-corrected). 
PSM3-CS011presents low SR ( $5 \mathrm{~cm} \cdot \mathrm{kyr}^{-1}, 3 \mathrm{~cm} \cdot \mathrm{kyr}^{-1}$ non-corrected $)$ between 26.7 and $30 \mathrm{kyr}$ BP (Fig. 18).

\subsubsection{Sedimentological characterisation}

Contourite drifts in the Pianosa CDS are mainly composed of bioturbated mud without lamination, although it is also common to find layers of bioclastic muddy sand. The abundance, grain size and bed thickness of these sandy layers changes along and across the Pianosa Ridge. Three Calypso piston cores sampled the sigmoid drift of zone 2: PSM3CS011, PSM3-CS009 and PSM3-CS012, recovering information from units 2 to 7. In general, contourites are muddy with sand contents around $10 \%$ of the total bulk volume (Figs. 16B and 17A). The sand is mainly composed of bioclasts. Decarbonated samples of core PSM3-CS011 (between 0 and $6.85 \mathrm{mbsf}$ ) present sand contents between 0.2 and $3 \%$ of the total volume in the range $63-150 \mu \mathrm{m}$. Bulk grain size analysis of the same samples showed sand volumes oscillating between 5 and $45 \%$ of the total volume in the range 63-1000 $\mu \mathrm{m}$ (Fig. 19). Some layers have higher sand contents (up to $70 \%$; Figs. 16B and 17A) and correspond to high amplitude reflections in the multi-channel and CHIRP seismic profiles and to increased Pwave velocities (Figs. 16 and 17B). The granulometry of PSM3-CS009 shows that D6 corresponds to a sandy layer coarsening-up until it reaches a maximum sand content of $70 \%$ and, then fining-up (Fig. 16B). Two radiocarbon analyses were carried out on planktonic foraminifera in core PSM3-CS009 on the muddy sediment over the sandy layer (at 11.26 mbsf) and under it (14.00 mbsf), resulting in approximately the same age: 30,000 cal yr BP (Table 1). Sand content in the contourite drift decreases with depth and with the distance to the moat. Therefore, PSM3-CS012 has a finer grain size than PSM3-CS009, especially remarkable in the coarser layers. For instance, the peak in P-wave velocity that corresponds to D6 in PMS3-CS012 (Fig. 16A) is less marked than in PSM3-CS009 (Fig. 16B). Another layer of coarser material can be found at 1.14 mbsf in core PSM3-CS009 and at 0.76 mbsf in core 
PSM3-CS012 that was deposited during the Younger Dryas (Fig. 16). PSM3-CS011 also shows coarser grain size at D6 and the Younger Dryas (Fig. 19A) and finer sediment during MIS2 (between YD and D6). Mean sortable silt values obtained from decarbonated samples of PSM3-CS011 between 0 and 6.85 mbsf increase during Heinrich Event 2 (HE2) and then a decrease during Dansgaard-Oeschger Event 2 (DO2; Figs. 17A and 19B). During MIS 2 mean sortable silt values tend to increase, reaching higher values in the Younger Dryas and, finally decreasing during the Holocene (Figs. 17A and 19B).

The multicrested mounded drifts of zone 4 were sampled by four Calypso piston cores along an east-west profile located at the south of the Elba Canyon (Figs. 12 and 20): PSM3-CS021, PSM3-CS006, PSM3-CS003, PSM3-CS020 (from the deepest to the shallowest core in water depth). These cores are between 9 and $22 \mathrm{~m}$ long and penetrated sediment from units from 1 to 7 . In zone 4 there is an evident decrease in grain size with water depth, sandy layers become less abundant, thinner and finer grained with depth (Fig. 20). The coarser layers are mainly composed of coarse grained bioclasts and mud, with abundant shells of bivalves, brachiopods (Gryphus vitreus) and fragments of the bryozoan Myriapora truncata. Some of the transitions between the sandy and the muddy layers are gradual, while others form sharp contacts (Fig. 20). The gradual transitions and the muddy layers located between two proximal sandy areas are commonly mottled mud with silty patches. The sandy layers are easily identified in the $\mathrm{P}$-wave velocity and in the $\mathrm{Ca} / \mathrm{Fe}$ curves since they correspond to faster P-wave velocities in sand and higher calcium content because of the bioclastic content.

\section{Discussion}

\subsection{Influence of seafloor morphology on contourite drift structure}

The evolution of contourite deposits is directly linked to water circulation influenced by the seafloor morphology. In the Pianosa CDS the effect of locally increased slopes and the 
occurrence of bulges clearly impacts the bottom-current pathways, and consequently the growth of the sediment drifts. For instance, a sigmoid drift is related to a bulge in the Pianosa Ridge at the south of the Pianosa Island (Fig. 6A).

The Elba Canyon seems to be a morphological depression originated as a graben in the basement and developed by sedimentation altered by bottom currents (Figs. 13 and 21). There are no evidences of active turbidity activity through this canyon since neither channel-levees system nor turbidite lobes have been observed related to this canyon. In addition, a shelf edge prism formed blocks the head of the canyon. This prism extends almost all along the Pianosa Ridge. Downslope processes probably exist all along the margin. They may transport coarser bioclastic material from the Tuscan Shelf to the contourite drifts. However, they do not seem to be high density flows saturated of sediment recurrent in time that result in the formation of turbidite lobes in the basin. The Elba Canyon does not seem to be a typical canyon of mixed turbidite-contourite processes that can be found for example in the Gulf of Cadiz (Brackenridge et al., 2013; Hernández-Molina et al., 2006; Marches et al., 2010) or in Antarctica (Rebesco et al., 2002). It is most probably a depression modelled mainly by bottom currents, by processes of differential erosion and deposition. It is an important difference because this is a continuous process, while in mixed turbidite-contourite canyons the effect of turbidity currents is only caused by discrete events separated in time.

Bottom-current circulation is more dynamic in the zone around the Elba Canyon. Firstly, the branches of the current are slightly deflected towards the NE and enter into the canyon. Secondly, part of the water may flow downslope along the canyon, eroding the northern flank and forming longitudinal incisions on it (Fig. 6B). At the end of the canyon, bottom currents may turn to the right and erode the bottom of the slope (Fig. 6B). Thirdly, the inclination of the reflections in the seismic profile of the water column located at the north of the Elba Canyon (Fig. 5) suggests the upwelling of deeper denser water to the upper slope that could 
be induced by the effect of the canyon on an alongslope current (Hickey, 1997; Klinck, 1996; Sobarzo et al., 2001). The development of the multicrested contourite drifts (Fig. 12), located at the south of the Elba Canyon at the present-day seafloor, is strongly subjected to the migration and evolution of the latter. Figure 12 registers the first aggradation in the centre of the canyon (step 2 in figure 21), followed by multiple destabilisations of the canyon flanks deposited on the axis of the canyon (steps 3-4 in figure 21). During this period, the canyon starts to migrate towards the north; later, a contourite drift is formed in the centre of the canyon (step 5 in figure 21). Afterwards, the canyon migrates farther north and contourites grow in its southern flank (step 6 in figure 21). Finally, a drift enters from the south into the canyon axis (steps 7-8 in figure 21). In summary, figure 12 documents the apparent complicated morphology of the sediment drifts because it was positioned in the middle of the canyon during a first phase and then it registers the southern flank of the canyon, since the latter migrated towards the north.

\subsection{Palaeoceanographic implications}

The Pianosa CDS presents a continuous development since the Middle-Late Pliocene (this study; Roveri, 2002), after the progressive filling of the deep central part of the basin (units Y/X and lower part of U1). This continuity implies that over the long-term the intermediate waters have had a similar circulation pattern flowing northwards along the Pianosa Ridge since the Middle-Late Pliocene. The concordance of the present-day oceanographic regime with the stratigraphic evolution of the contourite drifts (Fig. 4) suggests that the general circulation at the Pianosa Ridge has been similar during the history of the Pianosa CDS. The drift morphology is stable over time, only presenting a small component of upslope progradation (Fig. 9). The formation of oblique chimneys in pockmarks can also be a good indicator of the dominant currents direction. The interaction between bottom currents and fluid escape favours the deflection of the gas plume and thus differential erosion/deposition 
on pockmark flanks, resulting in erosion downstream and deposition upstream (Riboulot et al., 2014). Figure 4A shows that the mass transport deposit C3 is the origin of a pockmark that presents an oblique chimney. Since the MTD is a fixed source of fluid, the possible migration of pockmarks due to the migration or evolution of the fluid source can be rejected and, therefore it can be argued that the formation of an oblique chimney is mainly linked to the effect of bottom currents on the sedimentation at the pockmark.

From the Middle-Late Pliocene to the Middle Pleistocene (U1) the Pianosa CDS had a continuous growth of small mounded drifts. Afterwards, a prominent erosional surface (reflection D1) marks the onset of better-developed contourite mounded drifts (Fig. 8). The D1 reflection may correspond to the Middle Pleistocene Transition (MPT, 700-900 kyr). At this time, 100-kyr eccentricity cycles became dominant, resulting in longer glacial/interglacial cycles of higher amplitude, which might be related to the intensification of the Mediterranean Outflow Water (that is formed by the Mediterranean intermediate and deep waters) and the formation of a mid-Pleistocene discontinuity in the Gulf of Cadiz (Hernández-Molina et al., 2014). The onset of a stronger development of contourites in the Northern Tyrrhenian Sea coincides with the onset of the contourites along the Calabro-Tyrrhenian margin, in the Southern Tyrrhenian Sea (Amelio and Martorelli, 2008), suggesting that faster bottom currents in the depth range of the modern Levantine Intermediate Water impacted already the whole Tyrrhenian Sea.

\subsection{Glacial-interglacial stratigraphic evolution}

A model that describes the evolution of the sediment drifts in the Pianosa CDS is here proposed (Fig. 22). Contourite development in the Corsica Trough is mainly influenced by bottom-current velocity and sediment availability (that depends on the connection and disconnection of the turbidity systems), both directly influenced by climate changes. At 
present and since the beginning of the Holocene, the Golo Turbidite Network is disconnected (Calves et al., 2013) and bottom currents are slow in the Corsica Trough (this study; Toucanne et al., 2012). Therefore, during sea level high-stands sedimentation rates are low in the contourites (step 1 in figure 22). During sea level falls bottom currents are faster (this study; Toucanne et al., 2012) and their core may be located deeper in the slope, eroding the crest of the sediment drift. Under these conditions, most of the Tuscan Shelf was exposed, likely providing additional and coarser sediment to the slope. During this period of enhanced currents, bioclastic sands are deposited on the crest of the contourite (step 2 in figure 22). The deposition of sand beds may take place in a short period of time and may be the result of downslope processes that transport coarse material from the Tuscan Shelf to the slope, later reworked and winnowed by slope-parallel currents. D6 is a good example for this case because two radiocarbon dates show the same age (30 kyr) under and above the 3-m-thick sandy layer, proving a rapid formation of the deposit. In addition, the layer presents coarsening-up and posterior fining-up sequences that suggest the rework by bottom-currents. The evolution of the drift above the sandy layer (Fig. 22) leads to two different scenarios of the growth of a mounded drift in zone 2 between MIS 2 and MIS 1 (Case A), and between MIS 4 and MIS 3 (Case B). During MIS 2, sea level low-stand and the onset of the following sea level rise, bottom currents were fast in the Pianosa Ridge, but slower than during the sea level fall. As a result, bottom currents could transport large amounts of sediment but would not be fast enough to produce erosion on the drift. In addition, the turbidite system was connected (Calves et al., 2013) and provided sediment to the contourite system, resulting in a fast sedimentation of mud (step 3 for case A in figure 22), that sealed the sandy layer deposited during the sea level fall. This explanation is consistent with the heavy $\delta^{18} \mathrm{O}$ values found between the Younger Dryas and D6 in core PSM3-CS011 (Fig. 17A), proving the formation of the contourite during a cold period. On the contrary, in case B, during MIS 4 sea 
level low-stand the slope-parallel current velocity was probably very high, preventing sediment deposition, even if the turbidite system was connected (Calves et al., 2013), what would imply a sustained supply from the margin. This interpretation is sustained by the presence of light $\delta^{18} \mathrm{O}$ values between D6 and D5 that could not be formed during MIS4 (Fig. 17A). Afterwards, during MIS3 the relative sea level remained in between -60 and $-80 \mathrm{~m}$ (Fig. 17A), bottom currents likely slowed down but were still fast enough to transport large amounts of sediment, carried to the basin by recurrent turbidity currents (Calves et al., 2013). As a result, contourite drifts underwent a phase of accelerated growth during MIS 3 compared to MIS 4.

During the Younger Dryas there was no major erosion, but enhanced bottom currents were evident by the deposition of coarse sediment in the contourite drifts, with higher contents in sand (up to 50\% in cores PSM3-CS009 and PSM3-CS011; Figs. 16C, 17A and 19A) and higher sortable silt values in the basin floor (Figs. 17A and 19B; Toucanne et al., 2012; Minto'o et al., 2015). The deposition of sediment with higher sand contents during the Younger Dryas was also observed in the Gulf of Cadiz associated to the lower branch of the Mediterranean Outflow Water (Llave et al., 2006).

The reduced tectonic activity in the Corsica Trough since the early Pliocene (Zitellini et al., 1986) permits to recover a sedimentary record of the contourite depositional system that is only influenced by climate changes, by inducing fluctuations in sediment supply and bottom current velocity. The proposed model could be applied to the margins where sediment supply and bottom current velocity are enhanced during cold periods, as observed for example in the Gulf of Cadiz (Llave et al., 2006) or in glacial margins (Laberg et al., 2001; Rebesco et al., 2002).

\section{Conclusions}


The Pianosa Contourite Depositional System (CDS) is located in the confined basin of the Corsica Trough (Northern Tyrrhenian Sea) and it extends between 170 and $850 \mathrm{~m}$ water depth along $120 \mathrm{~km}$, with a maximum width of $10 \mathrm{~km}$. Contourite drifts are mainly composed of bioturbated mud, although sandy bioclastic layers are also common, more frequent, thicker and formed by coarser material in the shallowest areas. The morphology of the contourites is strongly controlled by the physiography of the Pianosa Ridge, especially the development of sigmoid drifts in the area where the Pianosa Ridge forms a bulge. Other irregularities or depressions of the seafloor, such as the Elba Canyon, alter locally the hydrodynamic regime and may induce the upwelling of denser waters, allowing the formation of shallower contourites. Different types of contourites can be found in the Pianosa CDS: plastered drift, separated elongated mounded drift, sigmoid mounded drift and multicrested drift. The onset of the Pianosa CDS occurred in the Middle-Late Pliocene, although the development of the contourite drifts was enhanced after the Middle Pleistocene Transition (700-900 kyr). The evolution of the system is continuous and coherent with the present-day circulation pattern, with the Levantine Intermediate Water flowing northwards along the eastern margin of the Corsica Trough. However, its velocity changed in the past with faster bottom currents during cold periods. During sea level falls, very fast bottom currents produced erosional surfaces on the drifts (more evident in the middle and upper slope). The accumulation of coarse bioclastic material in the contourites during sea level falls was favoured by the fact that the material from the continental shelf was more easily transported to the slope. The accumulation of fine sediment was greater during sea level low-stands than during sea level high-stands because the turbidite system was connected (providing fine sediment to the basin) and the velocity of bottom currents was relatively high (pirating the fine sediment from the turbidites and transporting it along the Pianosa Ridge).

\section{Acknowledgements}


We thank the Captain and the crew of the PRISME2-PAPRICA and PRISME3 cruises (2013) onboard R/V Atalante and R/V Pourquoi pas?, respectively. We are grateful to ISMAR-CNR for allowing us to have access to the seismic data from surveys ET91, ET93 and ET95, to M. Ligi for the processing of the sparker seismic reflection data and to the Collège Doctoral International of the Université Européene de Bretagne and the Conseil Régional de Bretagne for having awarded E. Miramontes with a travel grant during her stay at ISMAR-CNR. We would like to thank P. Dupont for the processing of the multi-channel high resolution seismic reflection data; S. Garziglia, S. Toucanne, N. Sultan, C. Pellegrini and V. Maselli for the insightful scientific discussion; A. Roubi and M. Rovere for the technical support and M. Payo Payo for helping with the visualisation of the grain size measurements. We are grateful to the guest editor C. Campbell and to the two anonymous reviewers for their valuable suggestions that improved the manuscript. The thesis of E. Miramontes and the cruise PRISME2PAPRICA are co-funded by TOTAL and Ifremer as part of the scientific project TOTAL-Ifremer PAMELA. We thank projects LabexMER ANR-10-LABX-19-01 Axis 4 for lab support.

\section{References}

Amelio, M., Martorelli, E., 2008. Seismo-stratigraphic characters of paleocontourites along the Calabro-Tyrrhenian margin (Southern Tyrrhenian Sea). Marine Geology 252, 141-149.

Angue Minto'o, C.M., 2014. Enregistrements sédimentaires des changements climatiques et environnementaux pendant le quaternaire terminal sur la marge Est-Corse. PhD Thesis, Université de Perpignan, Perpignan, 309.

Astraldi, M., Gasparini, G.P., 1992. The seasonal characteristics of the circulation in the north Mediterranean basin and their relationship with the atmospheric-climatic conditions. Journal of Geophysical Research: Oceans (1978-2012) 97, 9531-9540.

Bartole, R., 1995. The North Tyrrhenian-Northern Apennines post-collisional system: constraints for a geodynamic model. Terra Nova 7, 7-30.

Brackenridge, R.E., Hernández-Molina, F.J., Stow, D.A.V., Llave, E., 2013. A Pliocene mixed contourite-turbidite system offshore the Algarve Margin, Gulf of Cadiz: Seismic response, margin evolution and reservoir implications. Marine and Petroleum Geology 46, 36-50.

Cacho, I., Grimalt, J.O., Sierro, F.J., Shackleton, N., Canals, M., 2000. Evidence for enhanced Mediterranean thermohaline circulation during rapid climatic coolings. Earth and Planetary Science Letters 183, 417-429.

Calves, G., Toucanne, S., Jouet, G., Charrier, S., Thereau, E., Etoubleau, J., Marsset, T., Droz, L., Bez, M., Abreu, V., 2013. Inferring denudation variations from the sediment record; an example of the last glacial cycle record of the Golo Basin and watershed, East Corsica, western Mediterranean sea. Basin Research 25, 197-218.

Cattaneo, A., Jouet, G., Charrier, S., Thereau, E., Riboulot, V., 2014. Submarine Landslides and Contourite Drifts Along the Pianosa Ridge (Corsica Trough, Mediterranean Sea). 
Submarine Mass Movements and Their Consequences: 6th International Symposium 37, 435-445.

Deptuck, M.E., Piper, D.J.W., Savoye, B., Gervais, A., 2008. Dimensions and architecture of late Pleistocene submarine lobes off the northern margin of East Corsica. Sedimentology 55, 869-U834.

Fontanier, C., Mackensen, A., Jorissen, F.J., Anschutz, P., Licari, L., Griveaud, C., 2006. Stable oxygen and carbon isotopes of live benthic foraminifera from the Bay of Biscay: Microhabitat impact and seasonal variability. Marine Micropaleontology 58, 159-183.

Garziglia, S., 2010. Typologie, phénoménologie et approche des facteurs déclenchants des glissements sous-marins: application aux deltas profonds du Nil et du Niger. PhD Thesis, Université de Nice, 306-307.

Gervais, A., Savoye, B., Piper, D.J.W., Mulder, T., Cremer, M., Pichevin, L., 2004. Present morphology and depositional architecture of a sandy confined submarine system: the Golo turbidite system (eastern margin of Corsica). Confined Turbidite Systems 222, 59-89.

Gervais, A., Savoye, B., Mulder, T., Gonthier, E., 2006. Sandy modern turbidite lobes: A new insight from high resolution seismic data. Marine and Petroleum Geology 23, 485-502.

Grant, K.M., Rohling, E.J., Ramsey, C.B., Cheng, H., Edwards, R.L., Florindo, F., Heslop, D., Marra, F., Roberts, A.P., Tamisiea, M.E., 2014. Sea-level variability over five glacial cyces. Nature communications 5.

Harris, P.T., Beaman, R.J., 2003. Processes controlling the formation of the Mertz Drift, George Vth continental shelf, East Antarctica: evidence from $3.5 \mathrm{kHz}$ sub-bottom profiling and sediment cores. Deep Sea Research Part II: Topical Studies in Oceanography 50, 1463-1480.

Harris, P.T., Domack, E., Manley, P.L., Gilbert, R., Leventer, A., 1999. Andvord drift: A new type of inner shelf, glacial marine deposystem from the Antarctic Peninsula. Geology 27, 683-686.

Heezen, B.C., Hollister, C., 1964. Deep-sea current evidence from abyssal sediments. Marine Geology 1, 141-174.

Hernández-Molina, F.J., Somoza, L., Vázquez, J.T., Lobo, F., Fernández-Puga, M.C., Llave, E., Díaz-del Rio, V., 2002. Quaternary stratigraphic stacking patterns on the continental shelves of the southern Iberian Peninsula: their relationship with global climate and palaeoceanographic changes. Quaternary International 92, 5-23.

Hernández-Molina, F.J., Llave, E., Stow, D.A.V., García, M., Somoza, L., Vázquez, J.T., Lobo, F.J., Maestro, A., del Río, V.D., León, R., 2006. The contourite depositional system of the Gulf of Cadiz: a sedimentary model related to the bottom current activity of the Mediterranean outflow water and its interaction with the continental margin. Deep Sea Research Part II: Topical Studies in Oceanography 53, 1420-1463.

Hernández-Molina, F.J., Stow, D.A.V., Alvarez-Zarikian, C.A., Acton, G., Bahr, A., Balestra, B., Ducassou, E., Flood, R., Flores, J.-A., Furota, S., Grunert, P., Hodell, D., JimenezEspejo, F., Kim, J.K., Krissek, L., Kuroda, J., Li, B., Llave, E., Lofi, J., Lourens, L., Miller, M., Nanayama, F., Nishida, N., Richter, C., Roque, C., Pereira, H., Goni, M.F.S., Sierro, F.J., Singh, A.D., Sloss, C., Takashimizu, Y., Tzanova, A., Voelker, A., Williams, T., Xuan, C., 2014. PALEOCEANOGRAPHY Onset of Mediterranean outflow into the North Atlantic. Science 344, 1244-1250.

Hickey, B.M., 1997. The response of a steep-sided, narrow canyon to time-variable wind forcing. Journal of Physical Oceanography 27, 697-726.

Klinck, J.M., 1996. Circulation near submarine canyons: A modeling study. Journal of Geophysical Research: Oceans (1978-2012) 101, 1211-1223. 
La Violette, P.E., 1994. Overview of the major forcings and water masses of the Western Mediterranean Sea. Seasonal and Interannual Variability of the Western Mediterranean Sea, 1-11.

Laberg, J.S., Dahlgren, T., Vorren, T.O., Haflidason, H., Bryn, P., 2001. Seismic analyses of Cenozoic contourite drift development in the Northern Norwegian Sea. Marine Geophysical Researches 22, 401-416.

Lambe, T.W., Whitman, R.V., 1979. Soil mechanics S.I. version, second ed. Wiley, New York.

Lascaratos, A., Roether, W., Nittis, K., Klein, B., 1999. Recent changes in deep water formation and spreading in the eastern Mediterranean Sea: a review. Progress in Oceanography 44, 5-36.

Llave, E., Schonfeld, J., Hernández-Molina, F.J., Mulder, T., Somoza, L., del Rio, V.D., Sanchez-Almazo, I., 2006. High-resolution stratigraphy of the Mediterranean outflow contourite system in the Gulf of Cadiz during the late Pleistocene: The impact of Heinrich events. Marine Geology 227, 241-262

Marani, M., Argnani, A., Roveri, M., Trincardi, F., 1993. Sediment drifts and erosional surfaces in the central Mediterranean-seismic evidence of bottom-current activity. Sedimentary Geology 82, 207-220.

Marches, E., Mulder, T., Gonthier, E., Cremer, M., Hanquiez, V., Garlan, T., Lecroart, R., 2010. Perched lobe formation in the Gulf of Cadiz: Interactions between gravity processes and contour currents (Algarve Margin, Southern Portugal). Sedimentary Geology 229, 8194.

McCave, I.N., Hall, I.R., 2006. Size sorting in marine muds: Processes, pitfalls, and prospects for paleoflow-speed proxies. Geochemistry Geophysics Geosystems 7.

McCave, I.N., Manighetti, B., Robinson, S.G., 1995. Sortable silt and fine sediment size/composition slicing: Parameters for palaeocurrent speed and palaeoceanography. Paleoceanography 10, 593-610.

Millot, C., 1999. Circulation in the Western Mediterranean Sea. Journal of Marine Systems 20, 423-442.

Millot, C., 2013. Levantine Intermediate Water characteristics: an astounding general misunderstanding! Scientia Marina 77, 217-232.

Millot, C., Taupier-Letage, I., 2005. Circulation in the Mediterranean sea, The Mediterranean Sea. Springer, pp. 29-66.

Minto'o, C.M.A., Bassetti, M.A., Morigi, C., Ducassou, E., Toucanne, S., Jouet, G., Mulder, T., 2015. Levantine intermediate water hydrodynamic and bottom water ventilation in the northern Tyrrhenian Sea over the past 56,000 years: New insights from benthic foraminifera and ostracods. Quaternary International 357, 295-313.

Miramontes; E., Cattaneo, A., Jouet, G., Garziglia, S., 2016. Implications of Sediment Dynamics in Mass Transport along the Pianosa Ridge (Northern Tyrrhenian Sea). Submarine Mass Movements and Their Consequences: 7th International Symposium 41, 301-309.

Mulder, T., Faugères, J.C., Gonthier, E., 2008. Mixed turbidite-contourite systems. Developments in Sedimentology 60, 435-456.

Nygard, R., Gutierrez, M., Gautam, R., Hoeg, K., 2004. Compaction behavior of argillaceous sediments as function of diagenesis. Marine and Petroleum Geology 21, 349-362.

Pascucci, V., 2002. Tyrrhenian Sea extension north of the Elba Island between Corsica and western Tuscany (Italy). Bollettino della Società geologica italiana 121, 819-828.

Pascucci, V., Merlini, S., Martini, I.P., 1999. Seismic stratigraphy of the Miocene-Pleistocene sedimentary basins of the Northern Tyrrhenian Sea and western Tuscany (Italy). Basin Research 11, 337-356. 
Pascucci, V., Martini, I.P., Sagri, M., Sandrelli, F., Nichols, G., Paola, C., Williams, E.A., 2007. Effects of transverse structural lineaments on the Neogene-Quaternary basins of Tuscany (inner Northern Apennines, Italy). Sedimentary Processes, Environments and Basins - A Tribute to Peter Friend, Special Publication 37, 155-183.

Pellegrini, C., Maselli, V., Trincardi, F., 2015. Pliocene-Quaternary contourite depositional system along the south-western Adriatic margin: changes in sedimentary stacking pattern and associated bottom currents. Geo-Marine Letters, 1-13.

Rebesco, M., Pudsey, C.J., Canals, M., Camerlenghi, A., Barker, P.F., Estrada, F., Giorgetti, A., 2002. Sediment drifts and deep-sea channel systems, Antarctic Peninsula Pacific Margin. Geological Society, London, Memoirs 22, 353-371.

Rebesco, M., Camerlenghi, A., Van Loon, A.J., 2008. Contourite Research: A Field in Full Development. Developments in Sedimentology 60, 3-10.

Reimer, P.J., Bard, E., Bayliss, A., Beck, J.W., Blackwell, P.G., Ramsey, C.B., Buck, C.E., Cheng, H., Edwards, R.L., Friedrich, M., Grootes, P.M., Guilderson, T.P., Haflidason, H., Hajdas, I., Hatte, C., Heaton, T.J., Hoffmann, D.L., Hogg, A.G., Hughen, K.A., Kaiser, K.F., Kromer, B., Manning, S.W., Niu, M., Reimer, R.W., Richards, D.A., Scott, E.M., Southon, J.R., Staff, R.A., Turney, C.S.M., van der Plicht, J., 2013. IntCal13 and Marine13 radiocarbon age calibration curves 0-50,000 years cal BP. Radiocarbon 55, 1869-1887.

Riboulot, V., Thomas, Y., Berne, S., Jouet, G., Cattaneo, A., 2014. Control of Quaternary sealevel changes on gas seeps. Geophysical Research Letters 41, 4970-4977.

Roveri, M., 2002. Sediment drifts of the Corsica Channel, northern Tyrrhenian Sea, in: Stow, D.AV., Pudsey, C.J., Howe, J.A., Faugères, J.-C., Viana, A.R. (Eds.), Deep-Water Contourite Systems: Modern Drifts and Ancient Series, Seismic and Sedimentary Characteristics. Geological Society, London, Memoirs, 22, 191-208.

Schmiedl, G., Pfeilsticker, M., Hemleben, C., Mackensen, A., 2004. Environmental and biological effects on the stable isotope composition of recent deep-sea benthic foraminifera, from the western Mediterranean Sea. Marine Micropaleontology 51, 129152.

Sobarzo, M., Figueroa, M., Djurfeldt, L., 2001. Upwelling of subsurface water into the rim of the Biobio submarine canyon as a response to surface winds. Continental Shelf Research 21, 279-299.

Toucanne, S., Jouet, G., Ducassou, E., Bassetti, M.A., Dennielou, B., Minto'o, C.M.A., Lahmi, M., Touyet, N., Charlier, K., Lericolais, G., Mulder, T., 2012. A 130,000-year record of Levantine Intermediate Water flow variability in the Corsica Trough, western Mediterranean Sea. Quaternary Science Reviews 33, 55-73.

Toucanne, S., Angue Minto'o, C.M., Fontanier, C., Bassetti, M.A., Jorry, S.J., Jouet, G., in press. Tracking rainfall in the northern Mediterranean borderlands during sapropel deposition. Quaternary Science Reviews.

Vandorpe, T.P., Van Rooij, D., Stow, D.A.V., Henriet, J.-P., 2011. Pliocene to Recent shallow-water contourite deposits on the shelf and shelf edge off south-western Mallorca, Spain. Geo-Marine Letters 31, 391-403.

Verdicchio, G., Trincardi, F., 2008a. Mediterranean shelf-edge muddy contourites: examples from the Gela and South Adriatic basins. Geo-Marine Letters 28, 137-151.

Verdicchio, G., Trincardi, F., 2008b. Shallow-water contourites. Developments in Sedimentology 60, 409-433.

Viana, A.R., Faugeres, J.C., Kowsmann, R.O., Lima, J.A.M., Caddah, L.F.G., Rizzo, J.G., 1998. Hydrology, morphology and sedimentology of the Campos continental margin, offshore Brazil. Sedimentary Geology 115, 133-157. 
Vignudelli, S., Gasparini, G.P., Astraldi, M., Schiano, M.E., 1999. A possible influence of the North Atlantic Oscillation on the circulation of the Western Mediterranean Sea. Geophysical Research Letters 26, 623-626.

Vignudelli, S., Cipollini, P., Astraldi, M., Gasparini, G.P., Manzella, G., 2000. Integrated use of altimeter and in situ data for understanding the water exchanges between the Tyrrhenian and Ligurian Seas. Journal of Geophysical Research-Oceans 105, 19649-19663.

Woerther, P., Bourillet, J.-F., Damy, G., Dussud, L., Sultan, N., 2012. Improving in piston coring quality with acceleration and pressure measurements and new insights on quality of the recovery. 8th International Marine Technicians Symposium, INMARTECH 2012, 25 and 28 September 2012, Texel, the Netherlands.

Zitellini, N., Trincardi, F., Marani, M., Fabbri, A., 1986. Neogene tectonics of the northern Tyrrhenian Sea. Giornale di Geologia 48, 2.

\section{TABLE CAPTION}

Table 1. Radiocarbon ages of cores PSM3-CS009, PSM3-CS011, PSM3-CS006 and PSM3-

CS021. The age dates were corrected for a marine reservoir effect of 400 years and calibrated using Calib 7.0.2 and the IntCal13 calibration curve (Reimer et al., 2013).

Table 2. Stratigraphic framework of the Pianosa Ridge. MIS: Marine Isotope Stage. MPT: Middle Plesitocene Transition. The name of unit boundaries in red colour is the original name used by Zitellini et al. (1986).

\section{FIGURE CAPTION}

Fig. 1. Bathymetry of the Mediterranean Sea with the circulation of the Levantine Intermediate Water (adapted from Millot and Taupier-Letage (2005)).

Fig. 2. Bathymetry of the Corsica Trough and cartography of the contourite drifts that form the Pianosa Contourite Depositional System and of the turbidite lobes of the Golo Turbidite Network.

Fig. 3. Multibeam bathymetric map of the Corsica Trough with the location of the seismic profiles, sediment cores and the borehole used in this study. Figure 16C location is represented by a red line superposed on the black line of figure 8 . The location of figures 6 and 11 is represented with dashed squares. 
Fig. 4. Current velocity in north-south direction (positive towards the north and negative towards the south) from hull-mounted ADCP, coupled with multi-channel high resolution mini GI gun seismic reflection profiles. (A) North-South profile PSM2-HR-009 and zoom showing the presence of a pockmark with an oblique chimney rooted in MTD C3. (B) EastWest profile PSM2-HR-061. The horizontal dashed blue line shows the general interphase between the Modified Atlantic Water (MAW) and the Levantine Intermediate Water (LIW) (Astraldi and Gasparini, 1992; La Violette, 1994; Millot, 1999; Toucanne et al., 2012). Mass Transport Deposits (MTDs) are outlined by green polygons. See figure 3 for seismic profile location.

Fig. 5. PSM2-HR-043 multi-channel high resolution mini GI seismic reflection profile of the water column and sedimentary succession located at the north of the Elba Canyon. The horizontal reflections located at $0.16-0.20 \mathrm{~s}$ TWT (120-150 m w.d.) are interpreted as the mixing zone between the Modified Atlantic Water (MAW) and the Levantine Intermediate Water (LIW). Inclined reflections in the water column located at 0.30-0.36 s TWT (225-270 m w.d.) and marked with white triangles show the upwelling of deeper and denser water on the slope, where a moat and a mounded drift are formed. See figure 3 for seismic profile location.

Fig. 6. (A) Multibeam bathymetry zoom of the southern area of the system evidencing the presence of sigmoid drifts, a separated mounded drift, a plastered drift, numerous pockmarks, a mass transport deposit (Pianosa Slump, C1) and an area of the slope very affected by masswasting processes. (B) Multibeam bathymetry zoom of the area around the Elba Canyon revealing the surface morphology of multicrested and sigmoid drifts, a pockmark field and a mass transport deposit (A) at the toe of the Elba Canyon. 
Fig. 7. (A) Uninterpreted and (B) interpreted PSM2-HR-074 multi-channel high resolution mini GI gun seismic reflection profile showing the main seismic unit boundaries in zone 1 of the Pianosa CDS. The mounded drift is separated from the escarpment by an abraded surface. See figure 3 for seismic profile location.

Fig. 8. (A) Uninterpreted and (B) interpreted PSM2-HR-064 multi-channel high resolution mini GI gun seismic reflection profile of zone 2 showing the main seismic unit boundaries and units of the Pianosa CDS. The location of Calypso piston cores PSM3-CS009 and PSM3CS012 is indicated with blue lines. See figure 3 for cores and seismic profile locations.

Fig. 9. (A) Uninterpreted and (B) interpreted PSM2-HR-037 multi-channel high resolution mini GI gun seismic reflection profile of zone 3 showing the main seismic unit boundaries and units of the Pianosa CDS. The contourite drift is separated from the shelf edge prism by an abraded surface. See figure 3 for seismic profile location.

Fig. 10. PSM2-HR-063 multi-channel high resolution mini GI gun seismic reflection profile, showing the formation of a mounded shape induced by a mass transport deposit. See figure 3 for seismic profile location.

Fig. 11. 3D-rendered image composed of PSM2-HR-046 (E-W) and PSM2-HR-004 (N-S) multi-channel high resolution mini GI gun seismic reflection profiles and multibeam bathymetry of zone 4 in the Pianosa CDS showing the Elba Canyon and multicrested drifts. Note that the number of crests of the contourite drifts increases towards the north, while the size of the crests decreases in the same direction. See figure 3 for location.

Fig. 12. (A) Uninterpreted and (B) interpreted PSM2-HR-054 multi-channel high resolution mini GI gun seismic reflection profile of zone 4 showing the main seismic unit boundaries and units of the Pianosa CDS in the zone of multicrested drifts. See figure 3 for seismic profile location. 
Fig. 13. PSM2-HR-015 multi-channel high resolution mini GI gun seismic reflection profile across the Elba canyon showing the northwards migration of the canyon and the formation of a contourite drift on the southern flank. See figure 3 for seismic profile location.

Fig. 14. ET93-P12B single-channel sparker seismic reflection profile showing two moats at 350 and $500 \mathrm{~m}$ water depth (w.d.) associated to an elongated separated mounded drift. See figure 2 for seismic profile location.

Fig. 15. ET93-P43 single-channel sparker seismic reflection profile showing a flat separated drift in zone 5 of the Pianosa CDS. See figure 2 for seismic profile location.

Fig. 16. (A) From left to right: Density from MSCL (black line) and water content (red dots) and P-wave velocity from MSCL (black lines) and celerimeter (green dots) of core PSM3CS012. (B) From left to right: grain size distribution, percentage of sand volume, density from MSCL (black line) and water content (red dots) and P-wave velocity from MSCL (black lines) and celerimeter (green dots) of core PSM3-CS009. Red stars represent the location of radiocarbon dates. (C) PSM2-CH-064 CHIRP profile showing the location of cores PSM3CS012 and PSM3-CS009 with red lines.

Fig. 17. (A) From the top to the bottom: relative sea level curve from Grant et al. (2014), $\delta^{18} \mathrm{O}$ stack of benthic foraminifera (Cibicides wuellerstorfi, Cibicidoides pachyderma and Cibicidoides kullenbergi) from borehole GDEC4-2 showing in blue colour the corresponding Marine Isotope Stages (MIS), $\delta^{18} \mathrm{O}$ stack of Uvigerina peregrina and Uvigerina mediterranea from core PSM3-CS011, percentage of sand volume from core PSM3-CS011, sortable silt mean grain size of the decarbonated fraction of core PSM3-CS011, XRF $\log (\mathrm{Ca} / \mathrm{Fe})$ of core PSM3-CS011, XRF $\log (\mathrm{Ca} / \mathrm{Fe})$ of core PSM3-CS012, XRF $\log (\mathrm{Ca} / \mathrm{Fe})$ of core PSM3-CS009 and percentage of sand volume of core PSM3-CS009. The Younger Dryas (YD) is indicated with a blue band, the Dansgaard-Oeschger event 2 (DO2) with a red band and unit boundaries 
D6 to D3 with grey bands. Note that the higher mean sortable silt values are found during the YD and Heinrich Event 2 (HE2). Low mean sortable silt values are present at DO2. Differences in the $\delta^{18} \mathrm{O}$ range between GDEC4-2 and PSM3-CS011 are caused by the use of different benthic foraminifera species (epifaunal foraminifera in GDEC4-2 and infaunal in PSM3-CS011). The $\log (\mathrm{Ca} / \mathrm{Fe})$ curve of PSM3-CS012 is not entirely represented through D6 because this part of the core has been used for geotechnical analysis. Correlation was also done using seismic correlation with borehole GDEC4-2. Additional support for the correlation can be found with the good coherence between the $\mathrm{XRF} \log (\mathrm{Ca} / \mathrm{Fe})$ curves of this study and the XRF Calcium curves presented by Calves et al. (2013) and Toucanne et al. (2012). Red stars represent the location of radiocarbon dates. (B) PSM2-CH-014 CHIRP profile showing the location of cores PSM3-CS011 and PSM3-CS009 with red lines and the seismic reflections that mark unit boundaries (D1 to D6).

Fig. 18. Age models for cores PSM3-CS009 (blue line), PSM3-CS012 (green line) and PSM3-CS011 (red line), covering the last $30 \mathrm{kyr}$ BP (Unit 7). Chronological tie points from borehole GDEC4-2 used for the three cores are represented with a black triangle, radiocarbon dates are represented as blue open circles for core PSM3-CS009 and red open circles for PSM3-CS011. Dashed lines are sedimentation rates for cores PSM3-CS009 (blue), PSM3CS012 (green) and PSM3-CS011 (red). Core depths used for the calculation of sedimentation rates were corrected for coring perturbations and compaction.

Fig. 19. (A) Bulk grain size distribution (colour graph) and sand volume percentage of the bulk sediment (black line and dots) of core PSM3-CS011. The Younger Dryas (YD) and the boundary units D6-D2 intervals are represented with dashed white lines. The white arrows show the general grain size tendency. (B) Decarbonated grain size distribution (colour graph) and mean sortable silt (black line and dots) of the decarbonated fraction of the upper $6.85 \mathrm{~m}$ of core PSM3-CS011. Note that most of the sand fraction disappears after removing 
carbonates from the sediment. The white arrows show the mean sortable silt tendency that can be interpreted in terms of palaeocurrent speed, suggesting faster bottom currents during the YD and the Heinrich Event 2 (HE2) and slower during the Dansgaard-Oeschger event 2 (DO2) and the Holocene. (C) Correlation of sortable silt (10-63 $\mu \mathrm{m}$ silt fraction) mean size with sortable silt percentage of the decarbonated fraction (right). The linear relationship between mean size of sortable silt and percentage of sortable silt, in a well sorted population, indicates a sorting processed controlled by current flow dynamics (McCave et al., 2006).

Fig. 20. Core log, P-wave velocity and XRF $\mathrm{Ca} / \mathrm{Fe}$ curves of cores PSM3-CS021, PSM3CS006, PSM3-CS003 and PSM3-CS020. Three photos show the main sedimentary facies, from left to right: mud, mottled mud with silty patches and a bioclastic sand interval with a sharp upper boundary. Colours in the logs represent the real colour of the sediment.

Fig. 21. Evolution of the Elba Canyon (profile N-S; Fig. 13) and the associated multicrested drift (profile E-W; Fig. 12) since the late Messinian. Note that the apparent complicated stacking pattern of the multicrested drifts is originated by the canyon migration and the interaction of a changing seafloor morphology with bottom currents.

Fig. 22. Scheme explaining the evolution of a contourite drift during a single sea level cycle controlled by sediment availability (connection/disconnection of the turbidite system) and bottom-current velocity. Two different scenarios are proposed: high sediment accumulation due to fast bottom currents and high sediment availability during sea level low-stand (case A) or during periods of medium relative sea level (case B). 


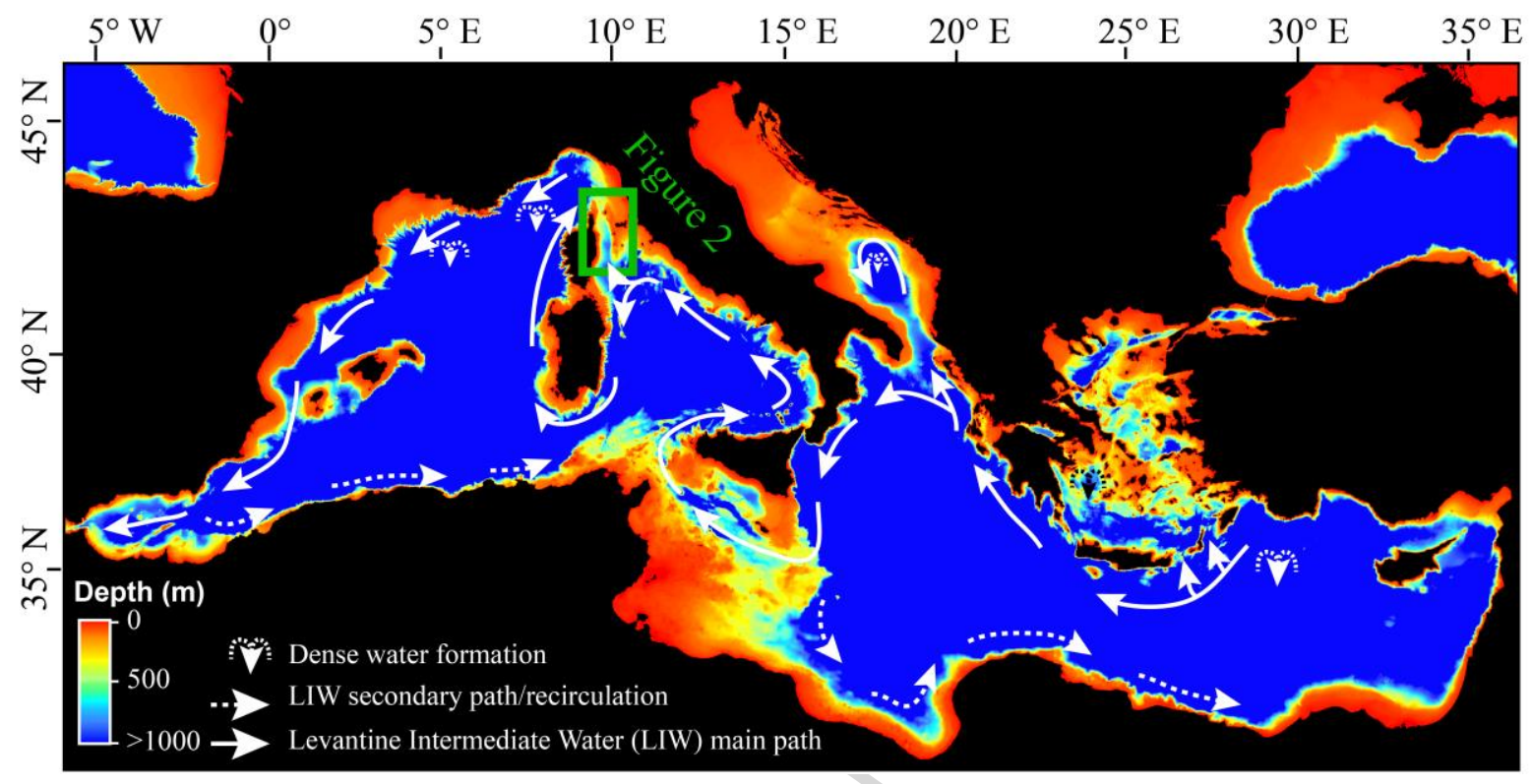

Fig. 1 


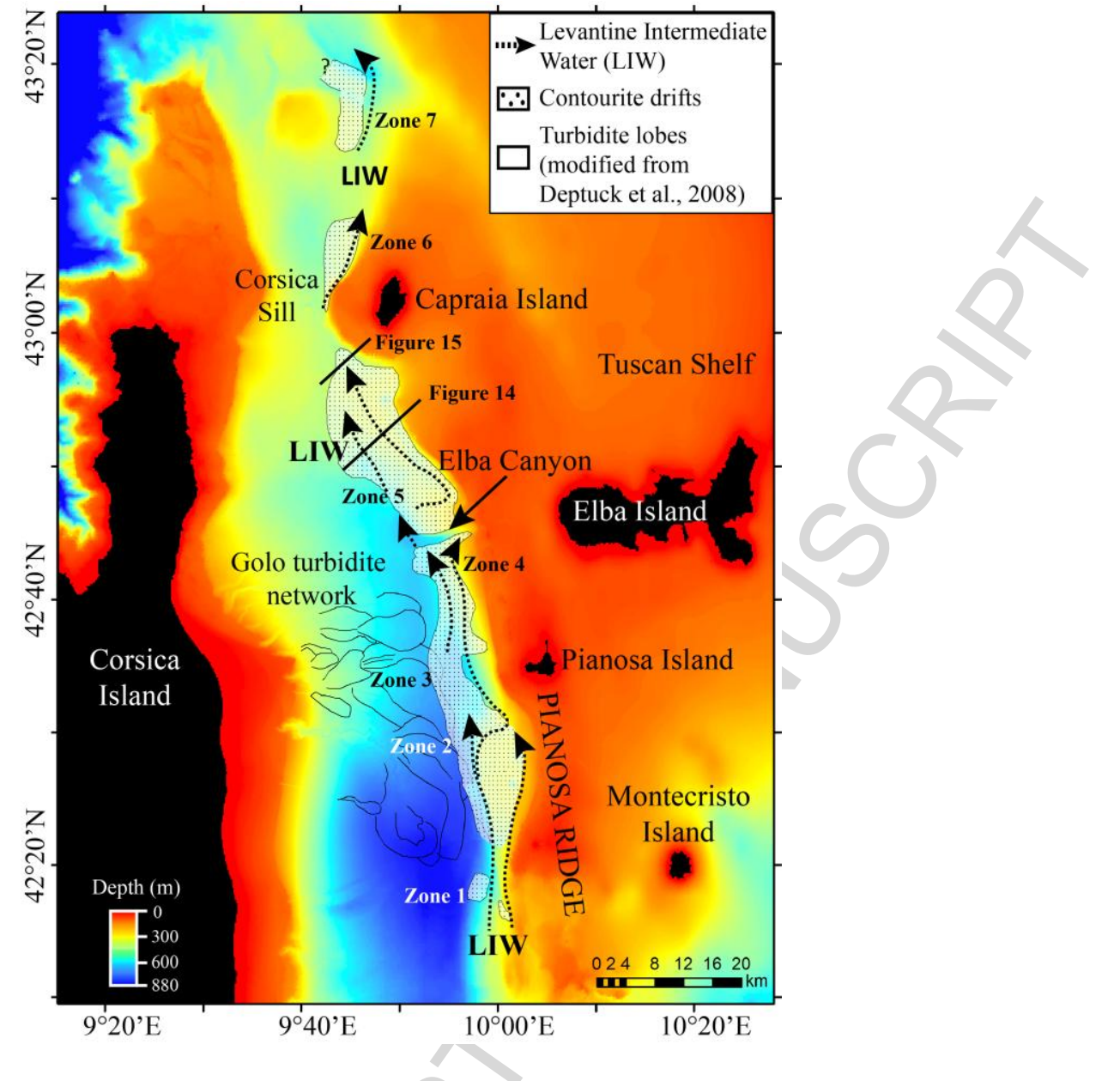

Fig. 2 


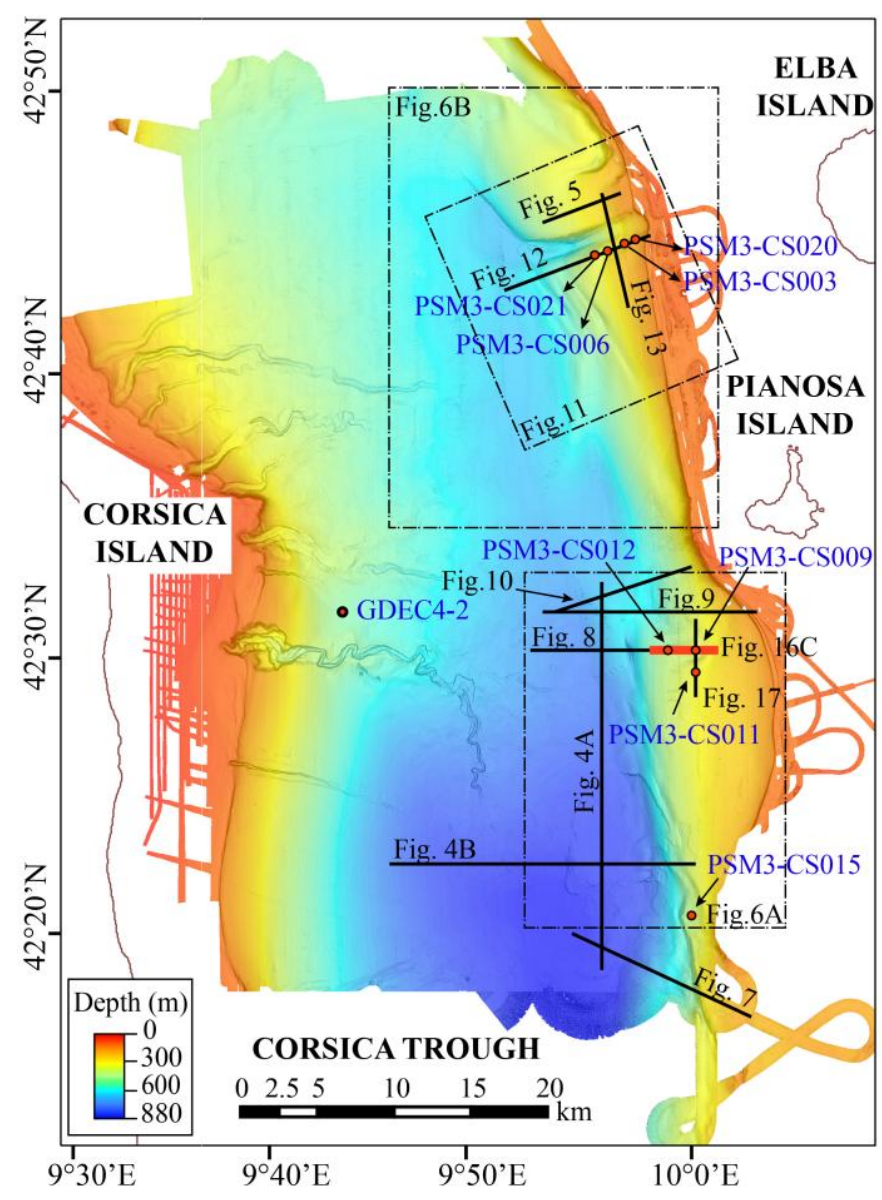

Fig. 3 


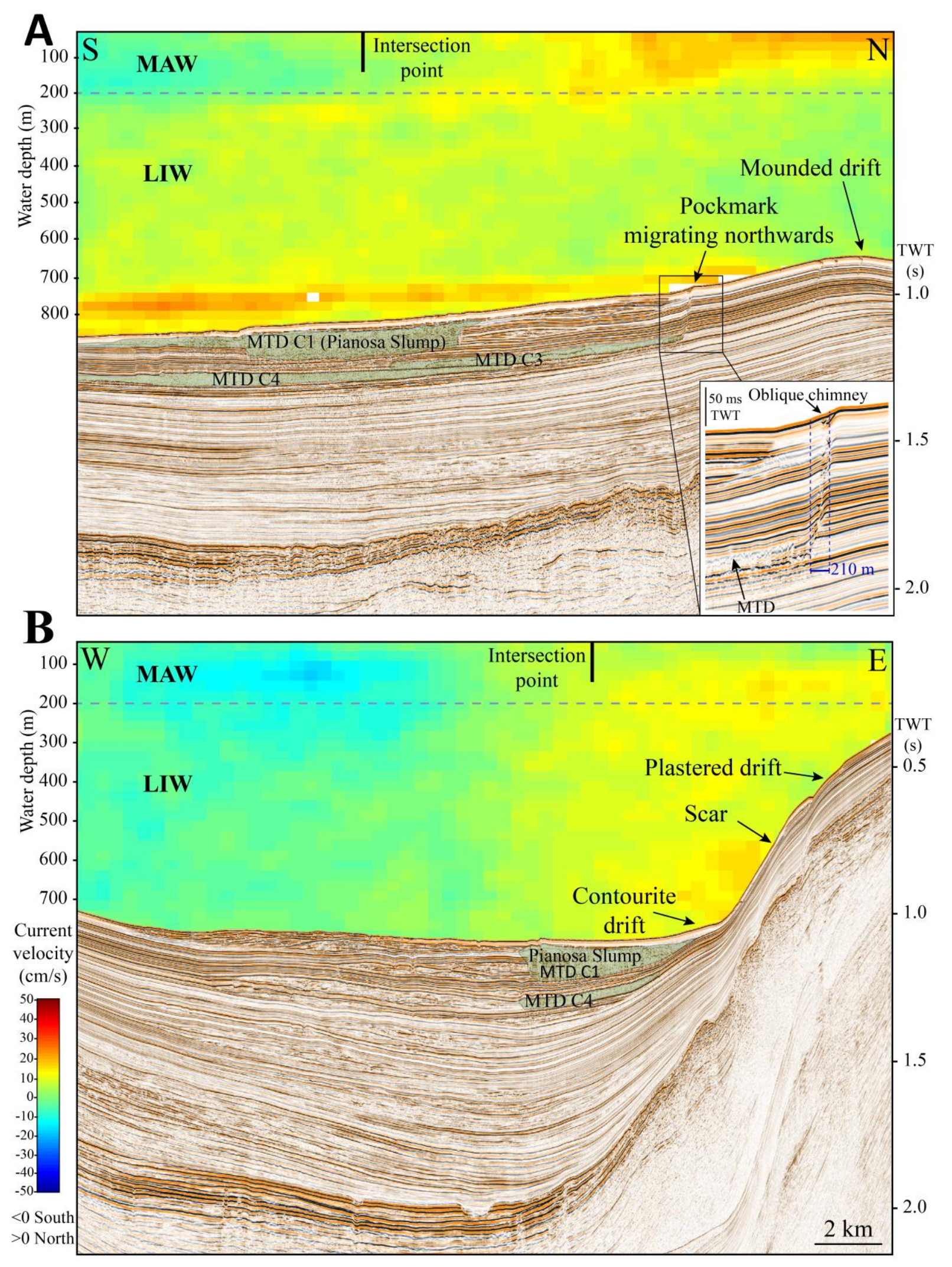

Fig. 4 


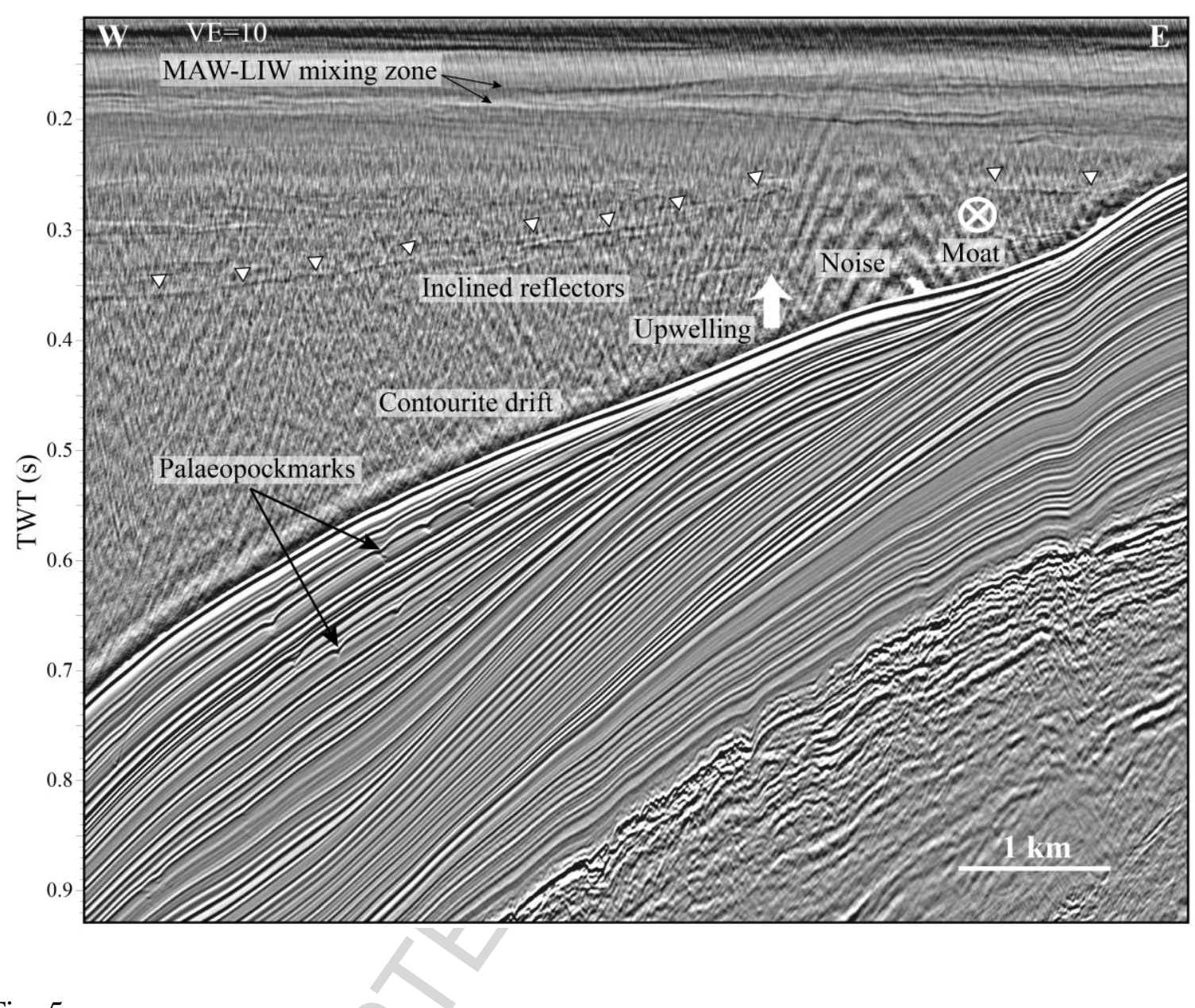

Fig. 5 


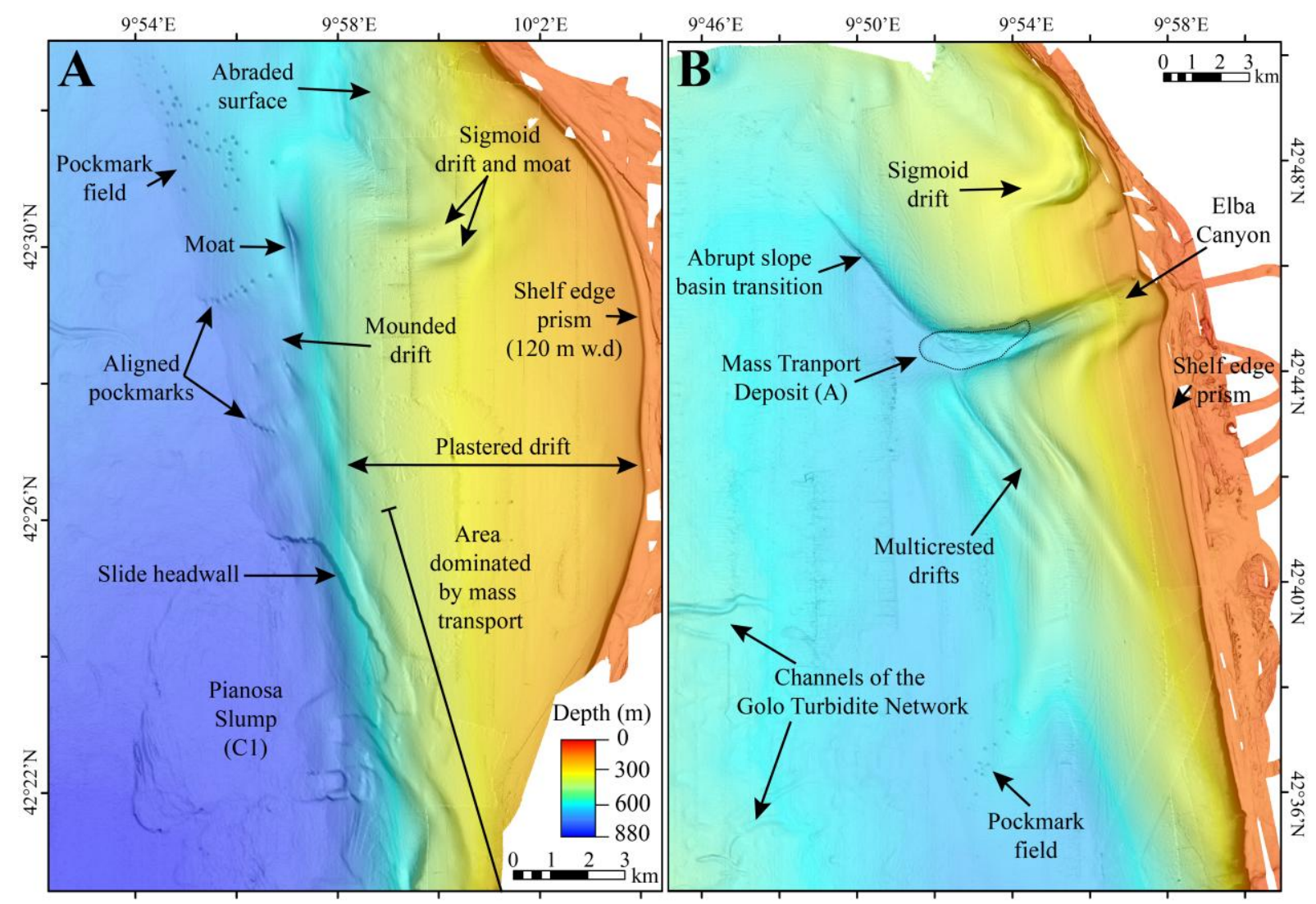

Fig. 6 


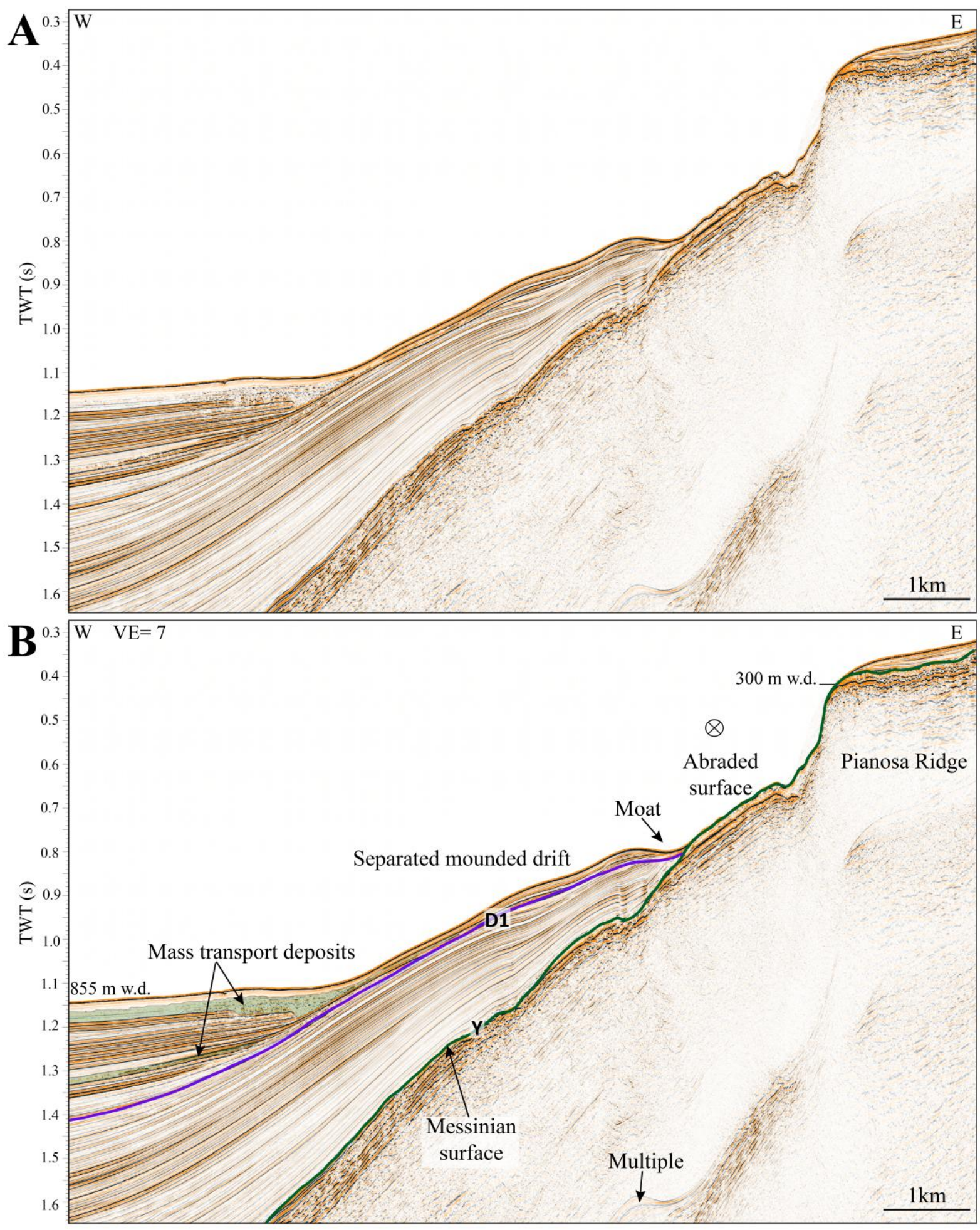

Fig. 7 

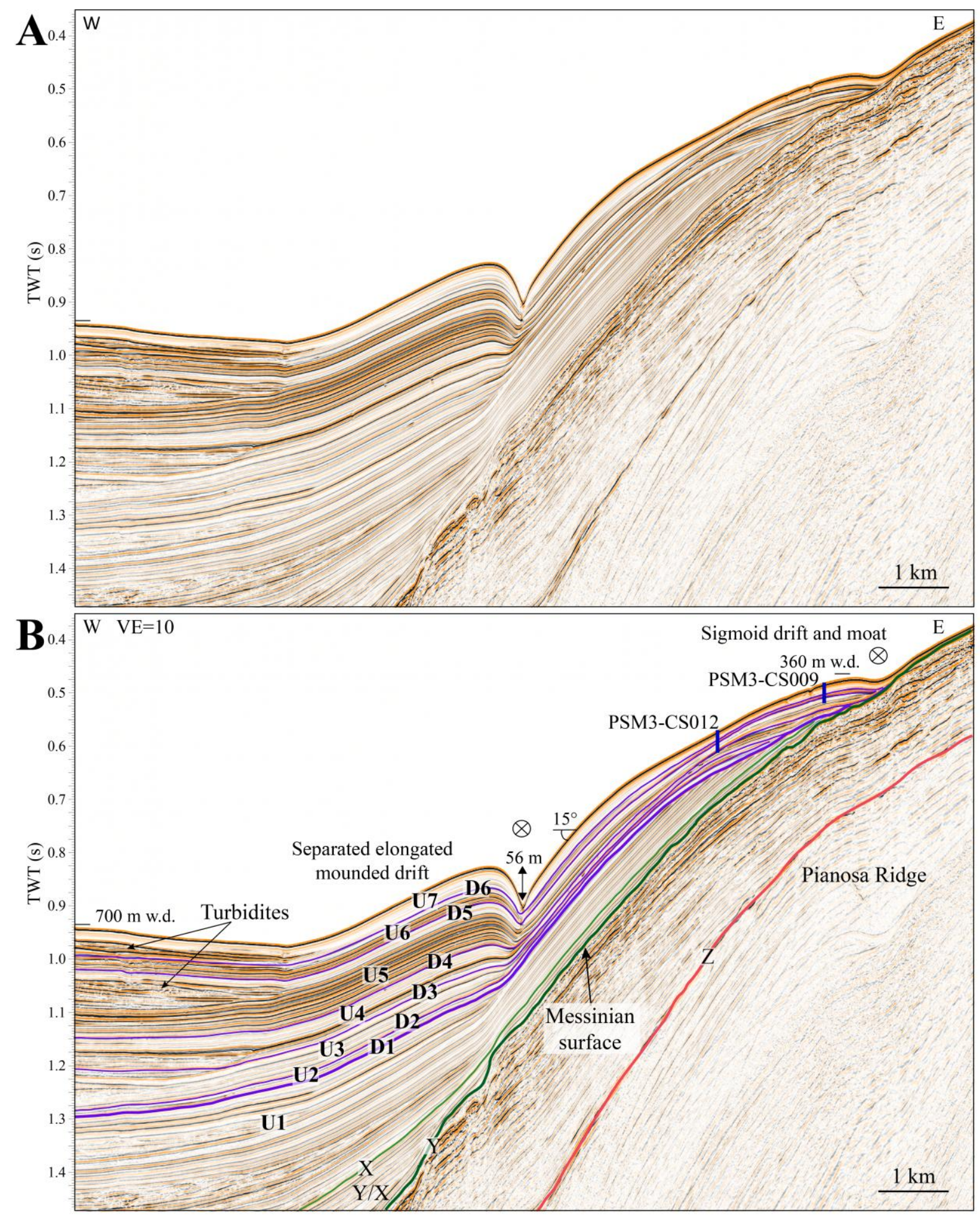

Fig. 8 


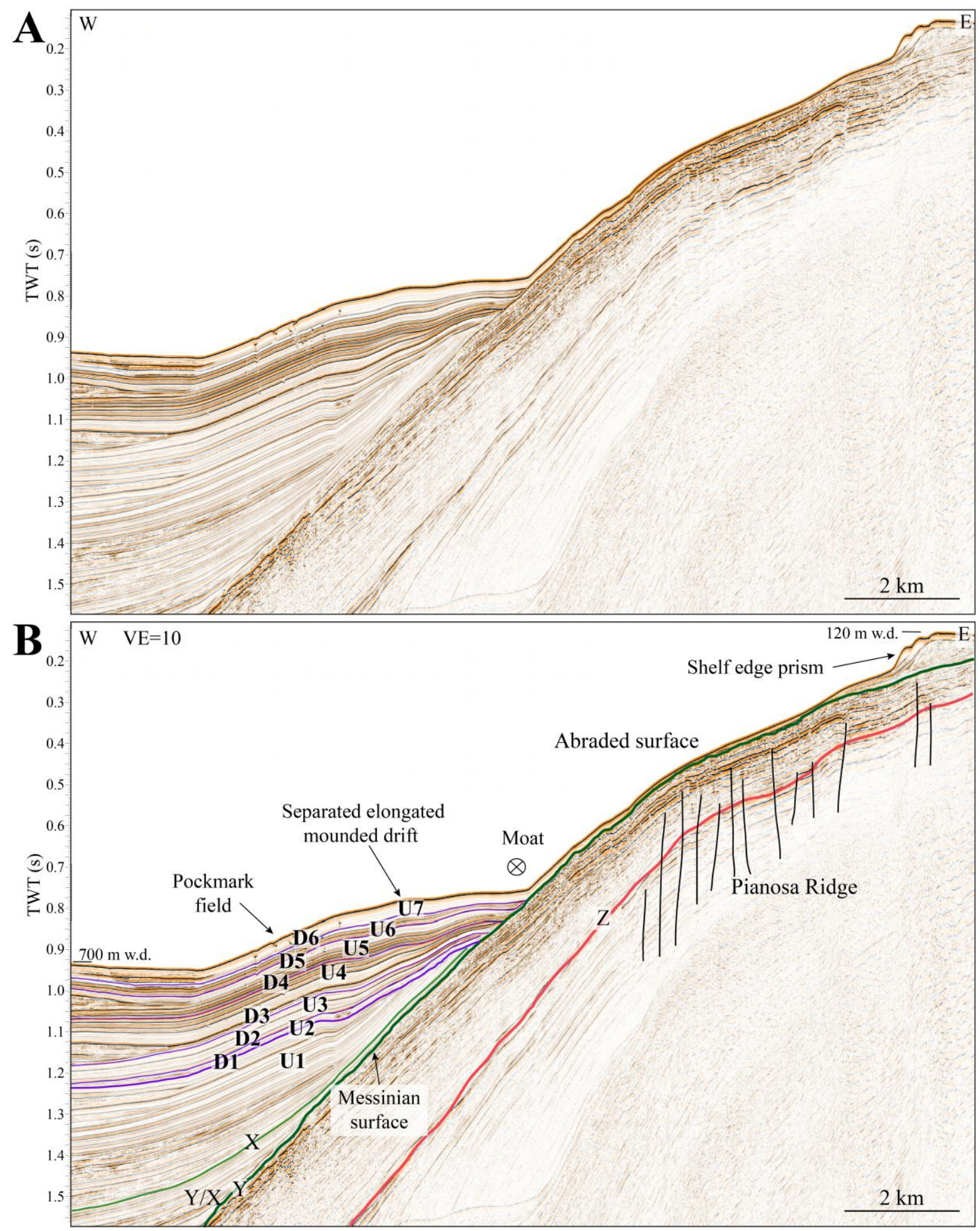

Fig. 9 


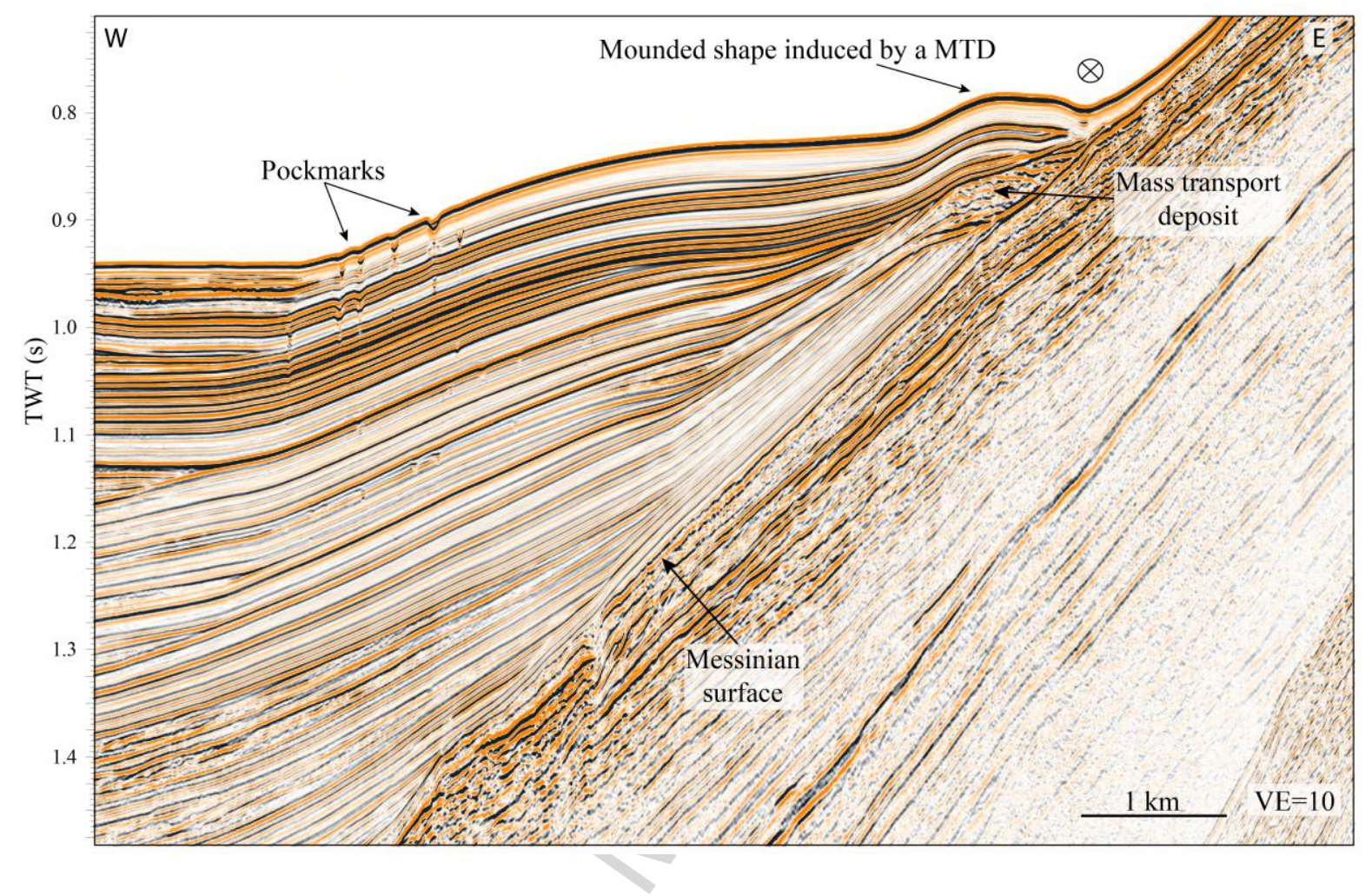

Fig. 10 


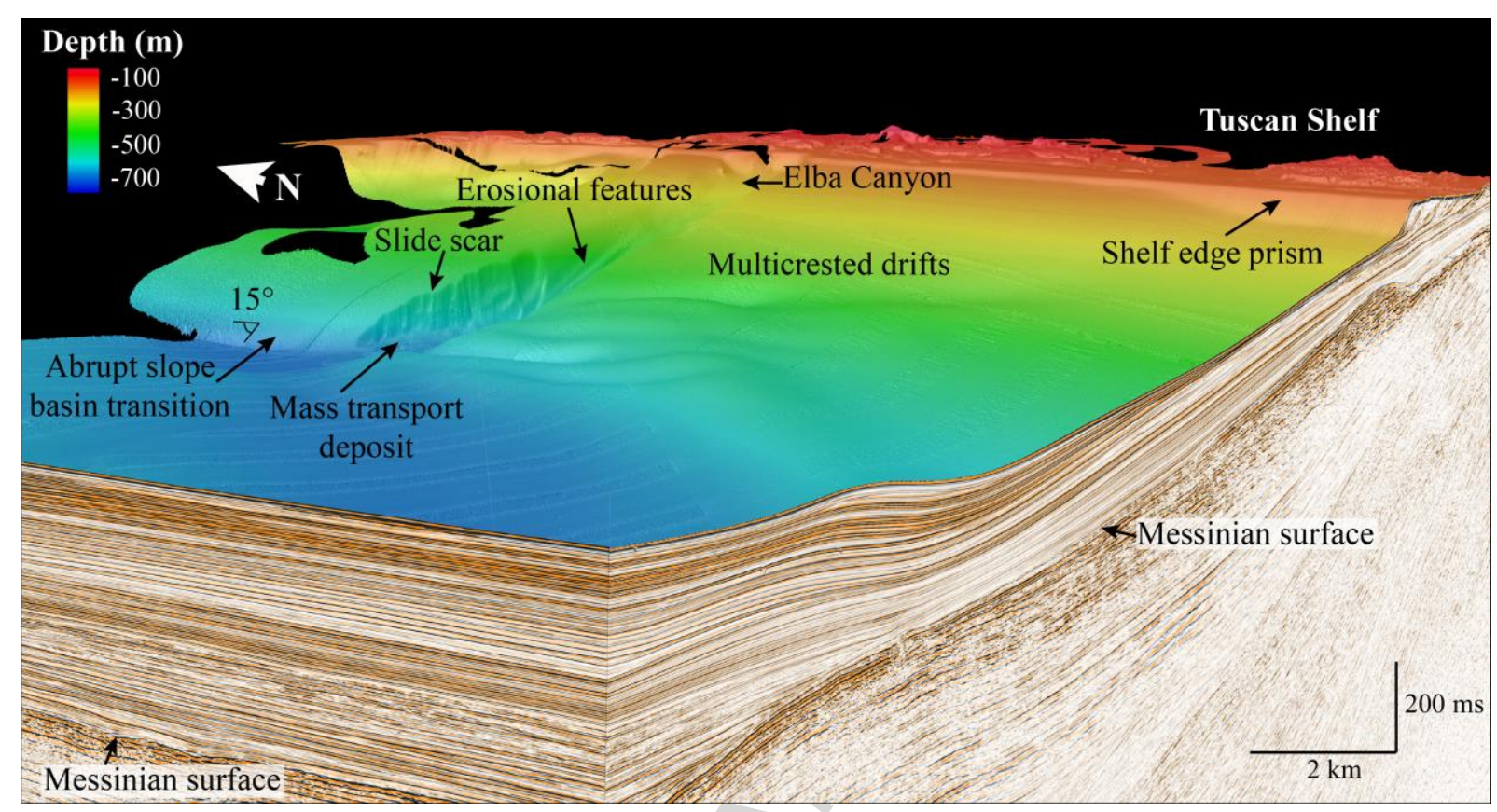

Fig. 11 

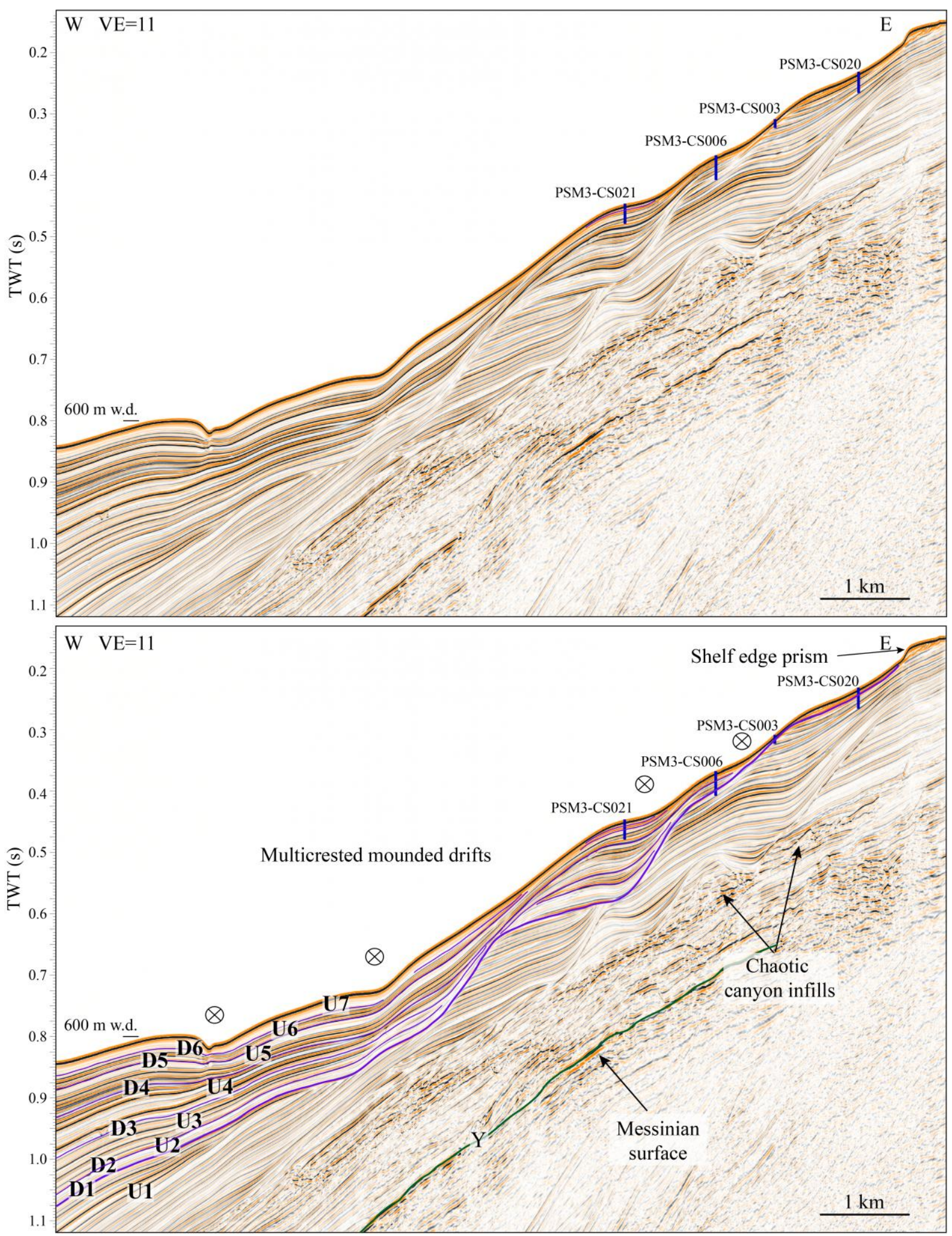

Fig. 12 


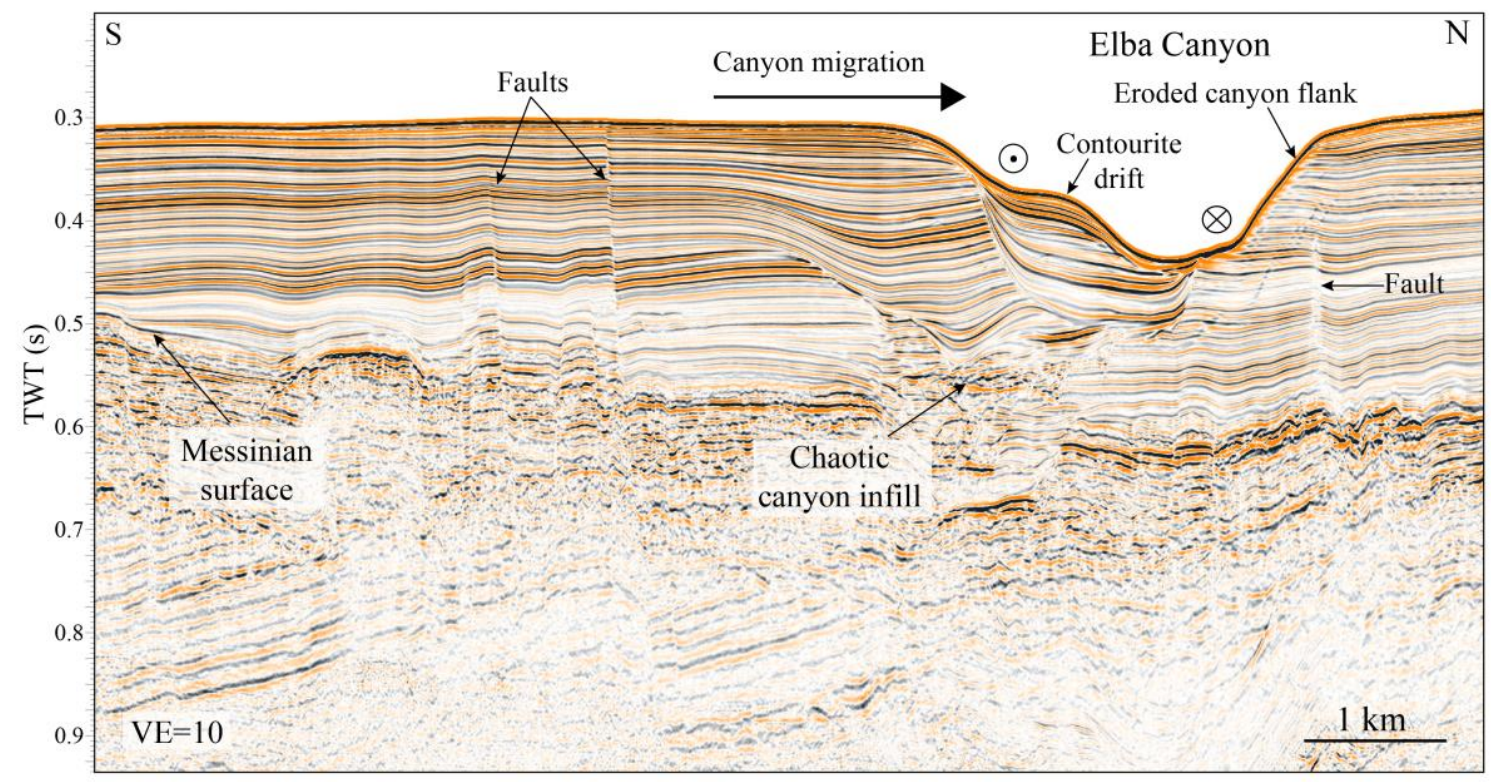

Fig. 13 


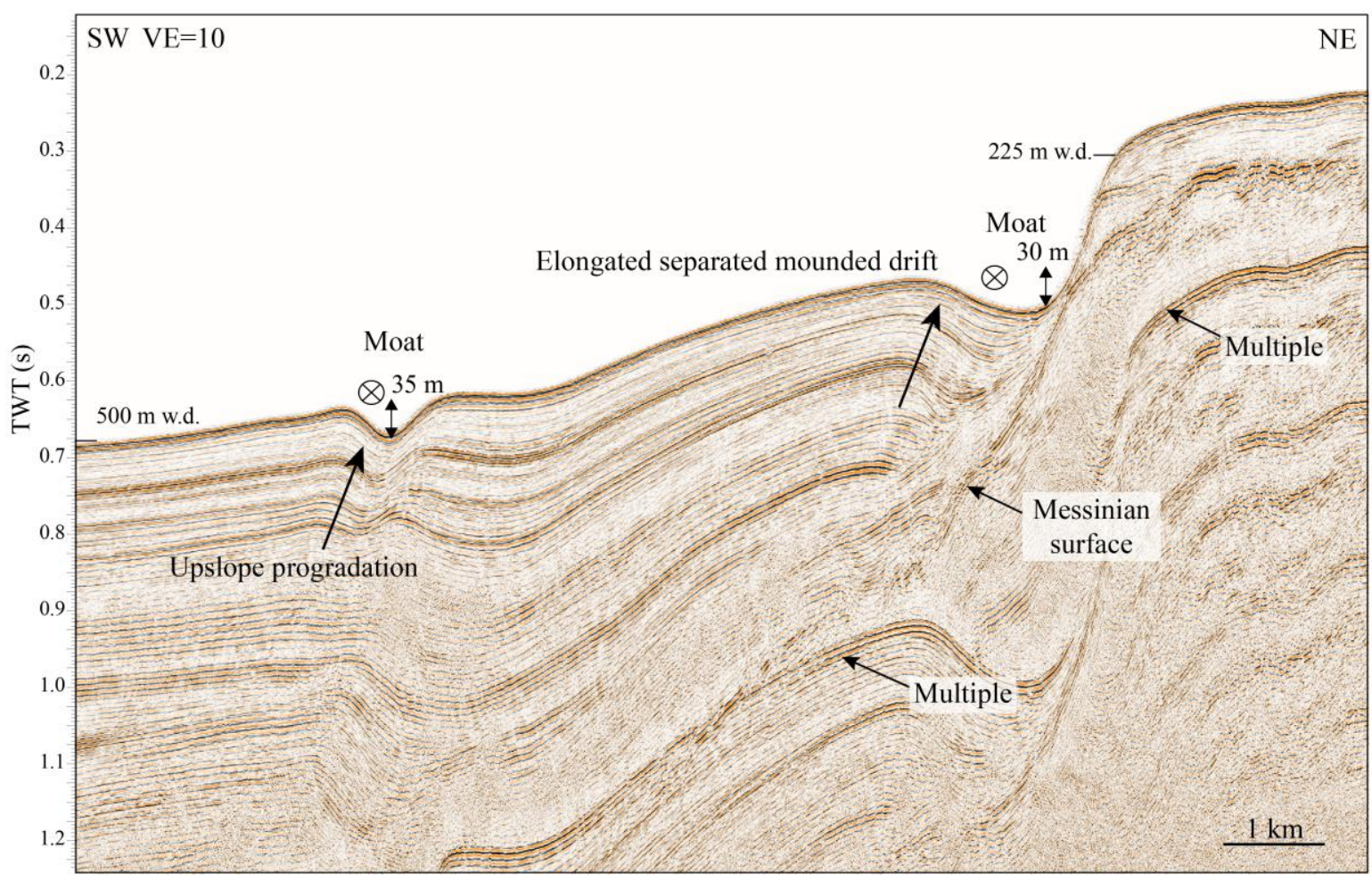

Fig. 14 


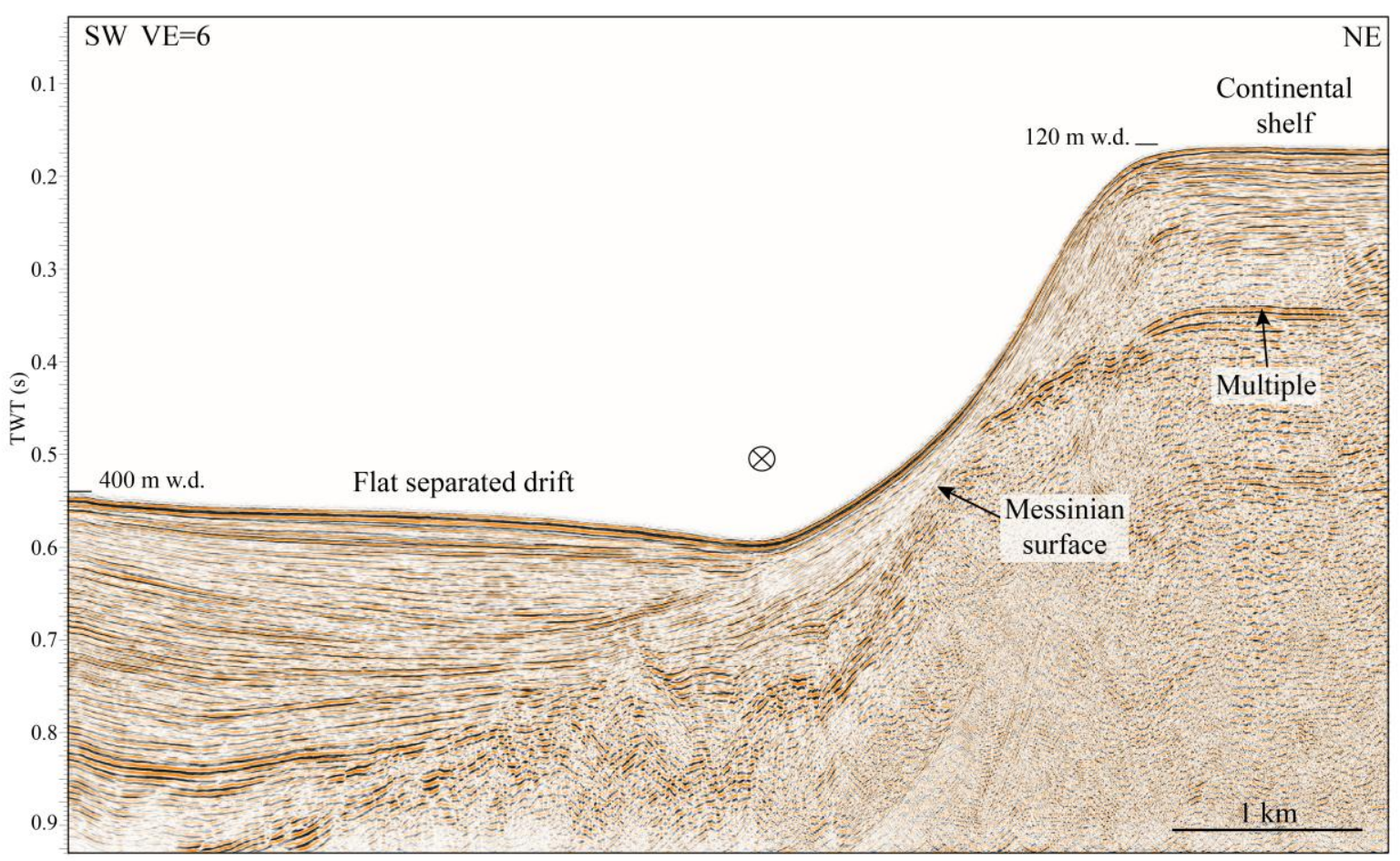

Fig. 15 
A PSM3-CS012 425 m w.d.

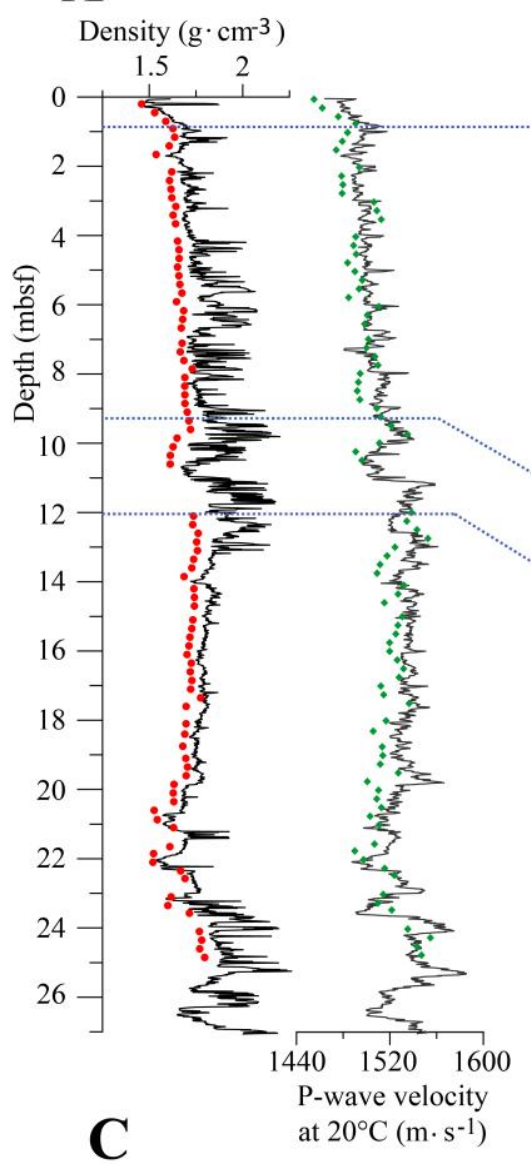

B PSM3-CS009 370 m w.d.

P-wave velocity

Sand volume (\%) at $20^{\circ} \mathrm{C}\left(\mathrm{m} \cdot \mathrm{s}^{-1}\right)$

$\begin{array}{llllllll}0 & 20 & 40 & 60 & 80 & 1440 & 1520 & 1600\end{array}$

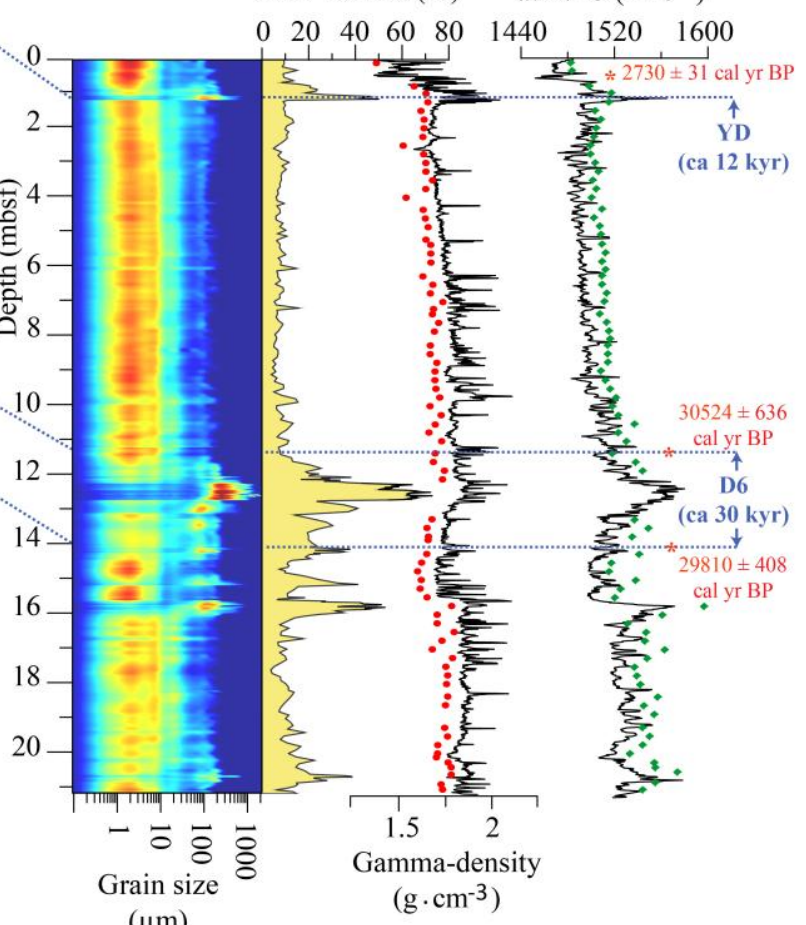

$(\mu \mathrm{m})$

Grain-size

mass frequency (\%)

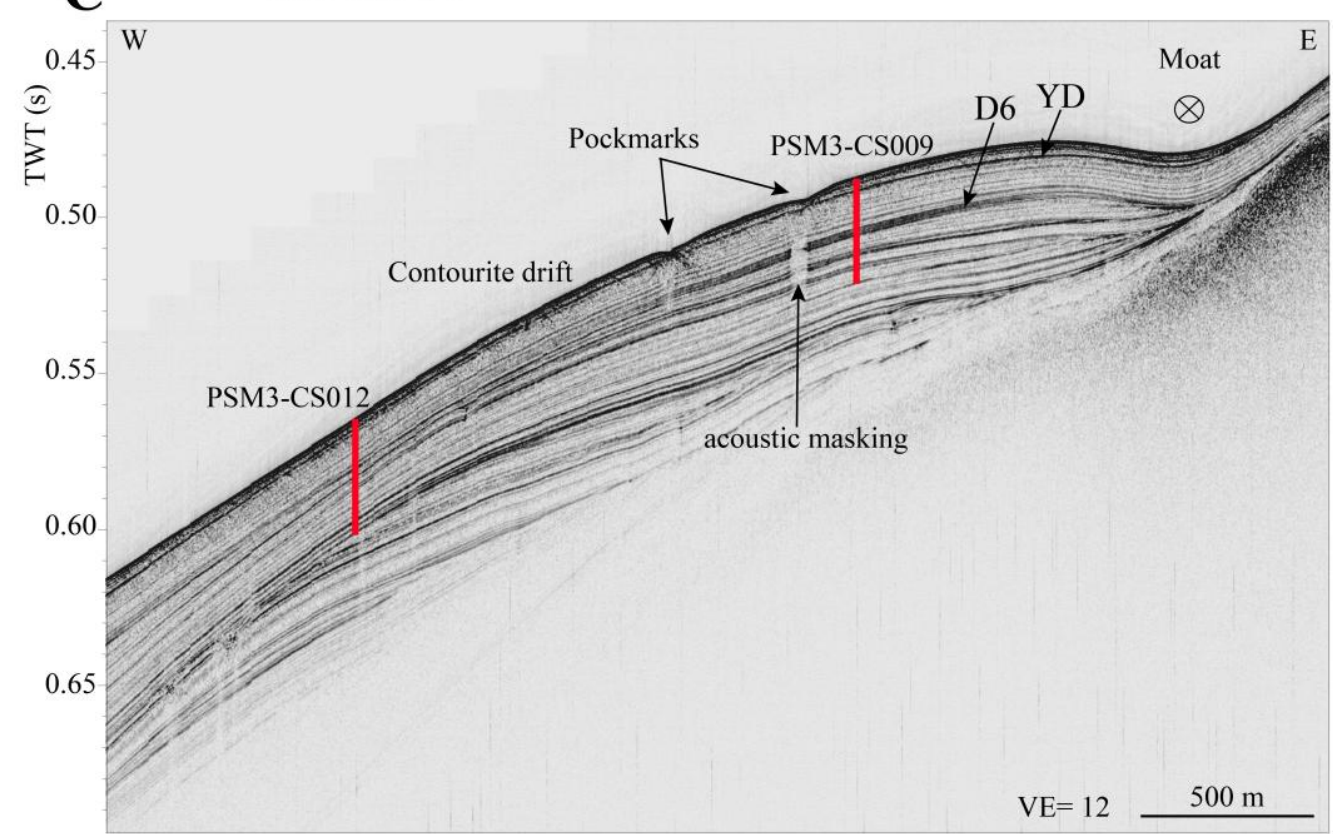

Fig. 16 


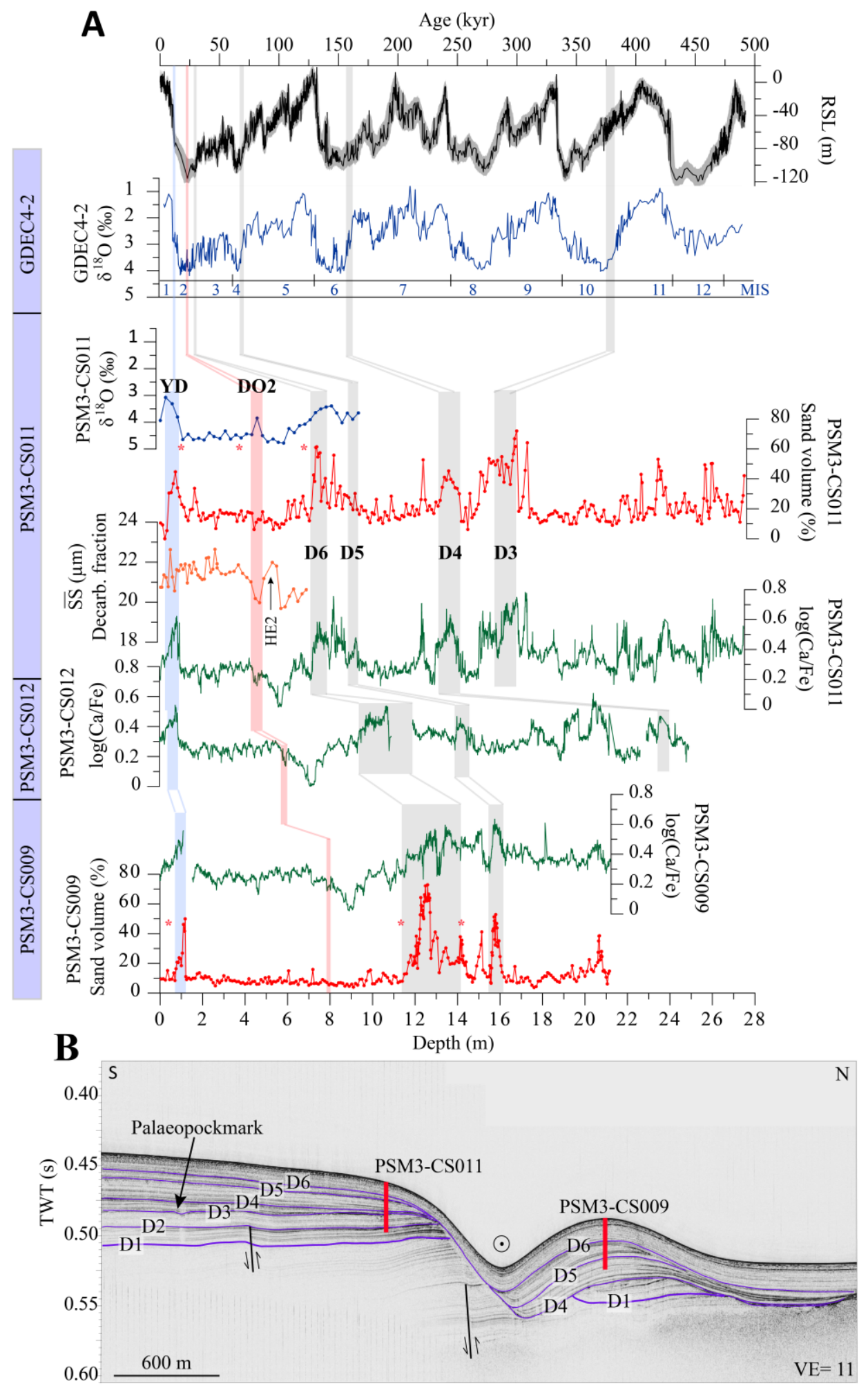

Fig. 17 


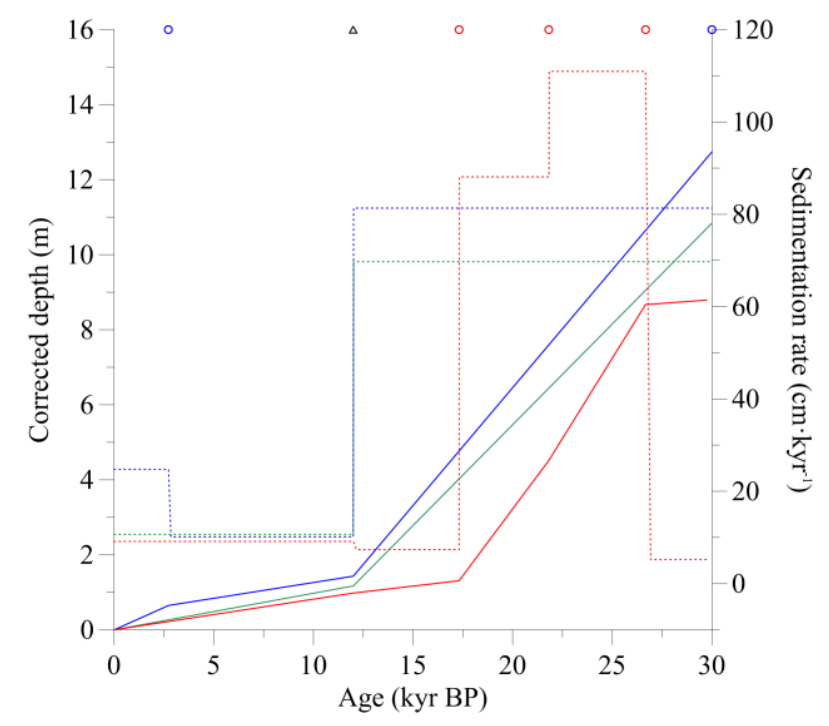

Fig. 18 

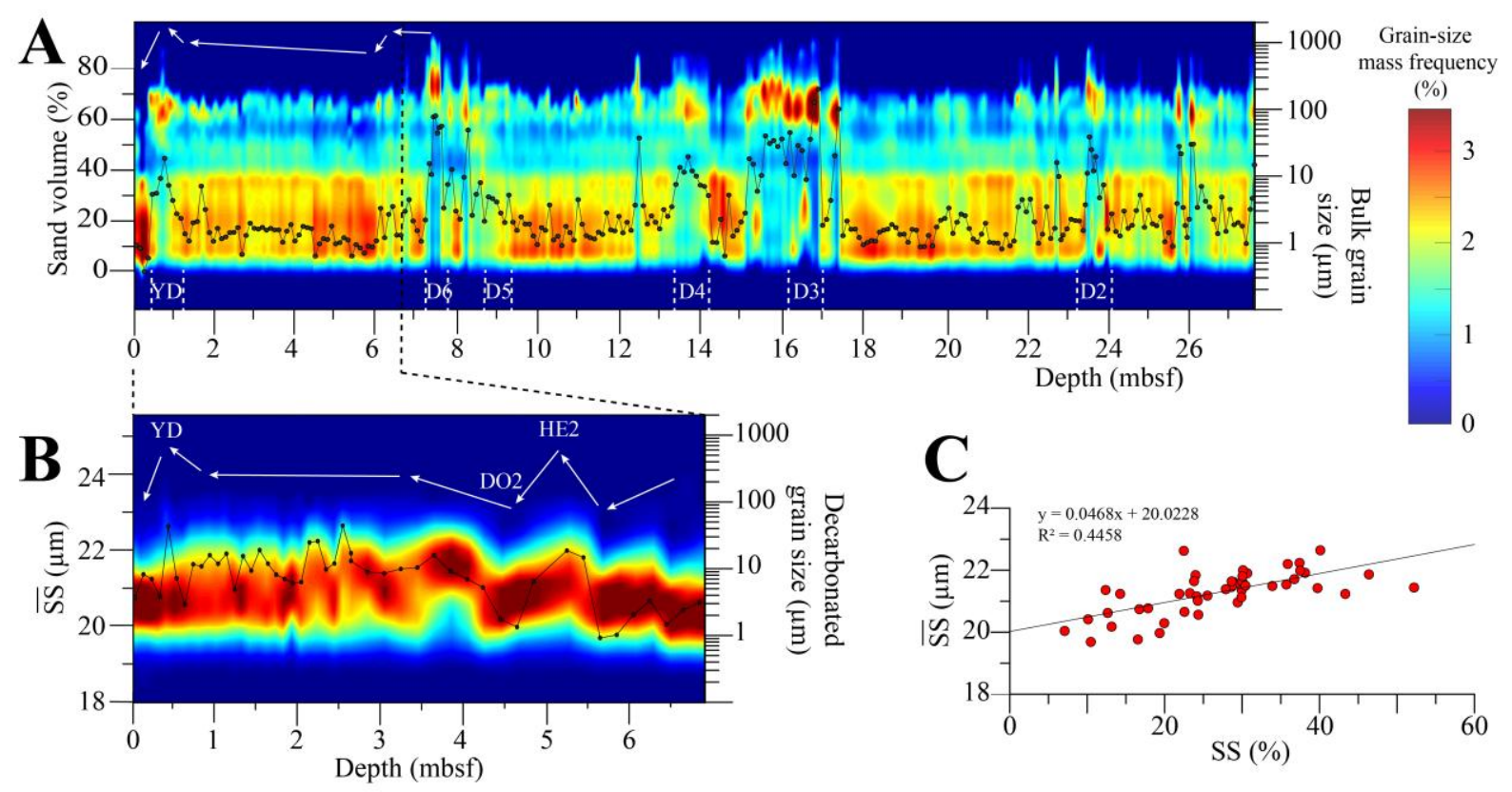

Fig. 19 


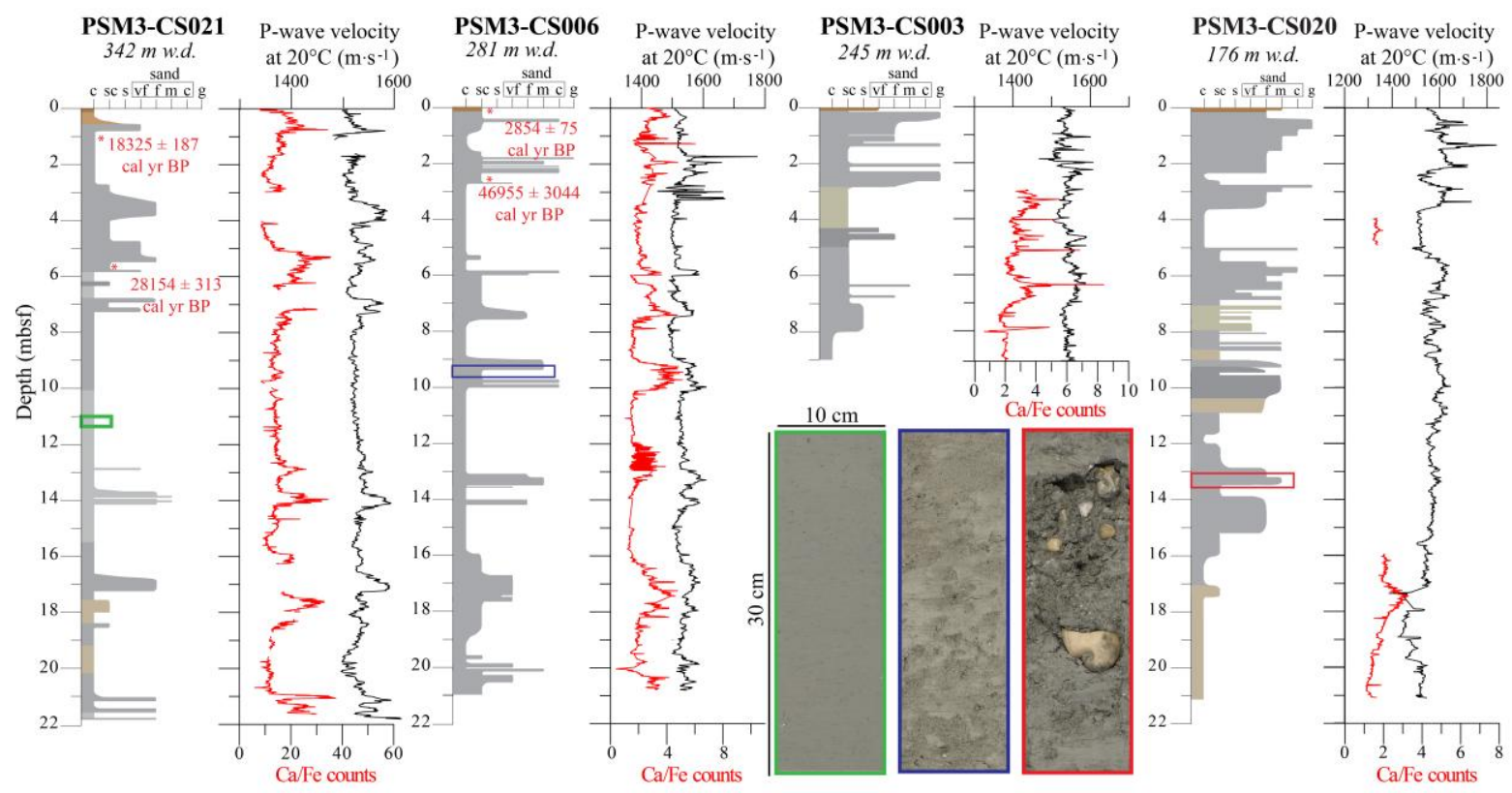

Fig. 20 

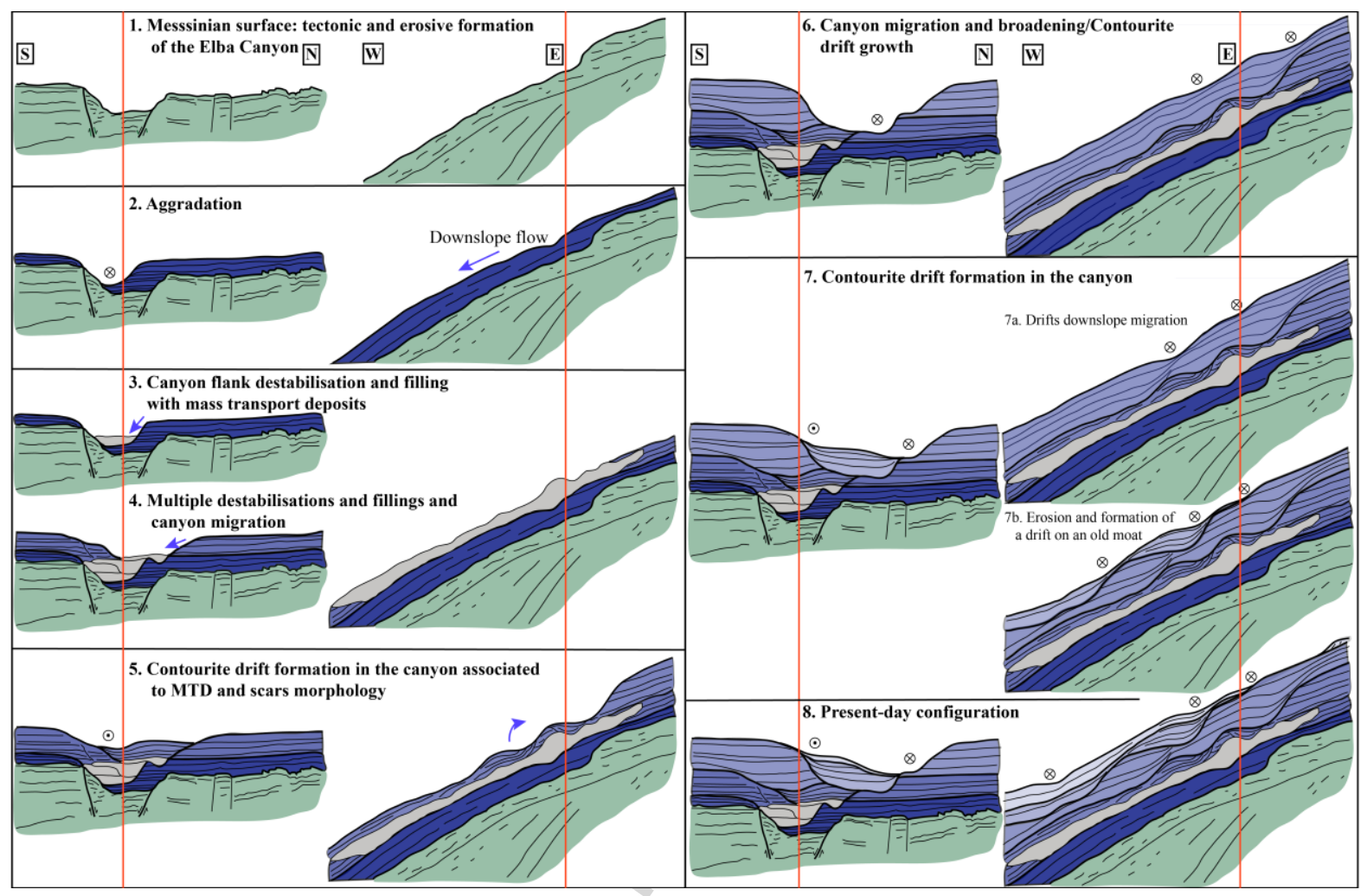

Fig. 21 


\begin{tabular}{|l|c|c|c|c|}
\multicolumn{1}{c}{} & \multicolumn{2}{c}{ Case A (MIS 2-MIS 1) } & \multicolumn{2}{c|}{ Case B (MIS 4 -MIS 3) } \\
\cline { 2 - 5 } \multicolumn{1}{c|}{} & $\begin{array}{c}\text { Sediment } \\
\text { availability }\end{array}$ & $\begin{array}{c}\text { Bottom-currents } \\
\text { velocity }\end{array}$ & $\begin{array}{c}\text { Sediment } \\
\text { availability }\end{array}$ & $\begin{array}{c}\text { Bottom-currents } \\
\text { velocity }\end{array}$ \\
\hline 1. Sea level high-stand & - & + & - & + \\
\hline 2. Sea level fall & - & +++ & - & +++ \\
\hline 3. Sea level low-stand & + & ++ & + & +++ \\
\hline 4. Sea level high-stand & \begin{tabular}{c} 
(maximum RSL) \\
\hline
\end{tabular} & + & $\begin{array}{c}+ \\
\text { (medium RSL) }\end{array}$ & ++ \\
\hline
\end{tabular}
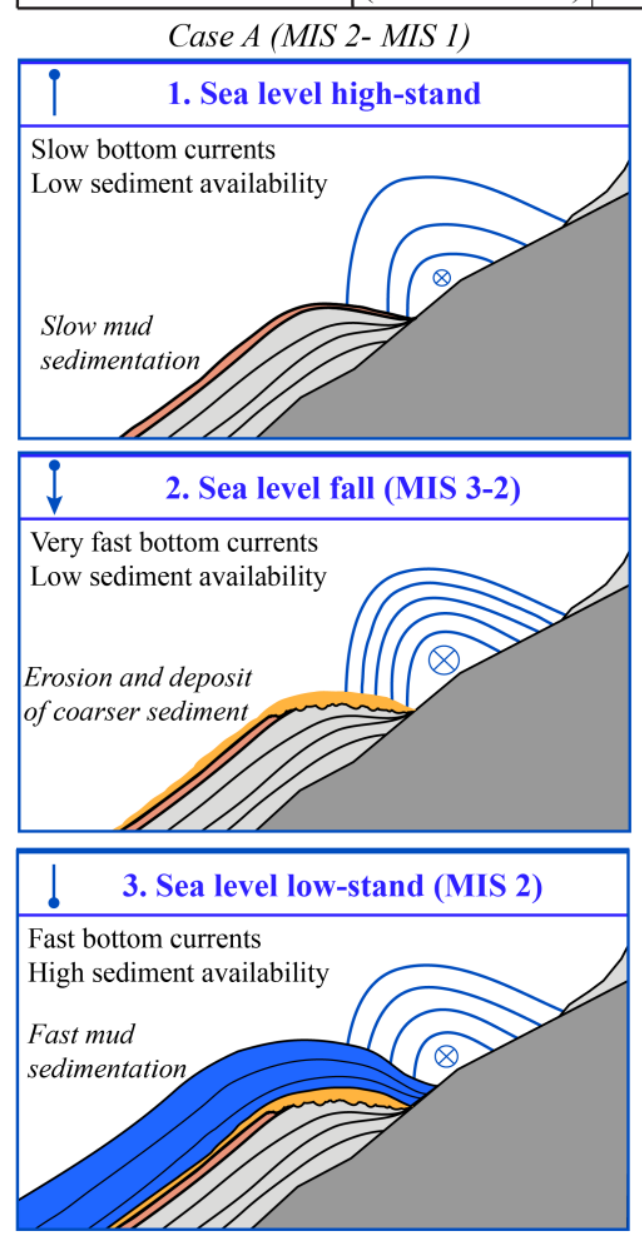

\section{Sea level high-stand (MIS 1)}

Slow bottom currents

Low sediment availability

Slow mud

sedimentation

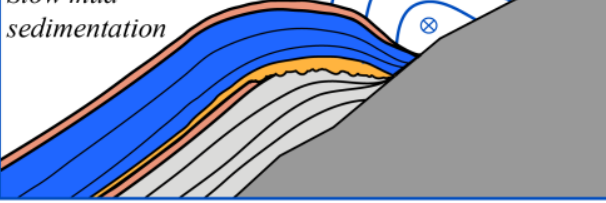

Case B (MIS 4- MIS 3)
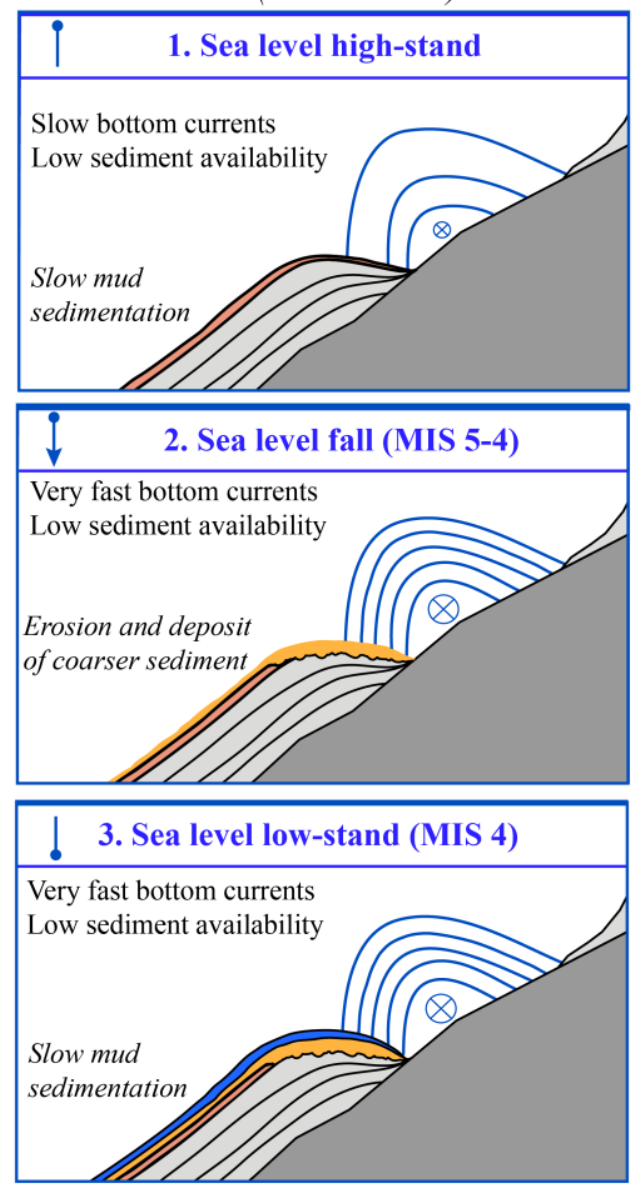

4. Sea level high-stand (MIS 3)

Fast bottom currents

High sediment availability

Fast mud

sedimentation

Fig. 22 


\begin{tabular}{llllll}
\hline Core number & Zone & Depth $(\mathrm{cm})$ & Material & Lab code & Cal BP age (yr) \\
\hline PSM3-CS009 & 2 & 41 & Bulk planktonic & Poz-63392 & $2,730 \pm 31$ \\
PSM3-CS009 & 2 & 1126 & Bulk planktonic & Poz-63393 & $30,524 \pm 636$ \\
PSM3-CS009 & 2 & 1400 & Bulk planktonic & Beta-394859 & $29,810 \pm 408$ \\
PSM3-CS011 & 2 & 104 & Bulk planktonic & Beta-394860 & $17,311 \pm 193$ \\
PSM3-CS011 & 2 & 380 & Bulk planktonic & Beta-394861 & $21,820 \pm 221$ \\
PSM3-CS011 & 2 & 709 & Bulk planktonic & Beta-394862 & $26,668 \pm 366$ \\
PSM3-CS006 & 4 & 7 & Bulk planktonic & Poz-63394 & $2,854 \pm 75$ \\
PSM3-CS006 & 4 & 250 & Bulk planktonic & Poz-63395 & $46,955 \pm 3,044$ \\
PSM3-CS021 & 4 & 100 & Bulk planktonic & Beta-394864 & $18,325 \pm 187$ \\
PSM3-CS021 & 4 & 550 & Bulk planktonic & Beta-394865 & $28,154 \pm 313$ \\
\hline
\end{tabular}

Table 1 


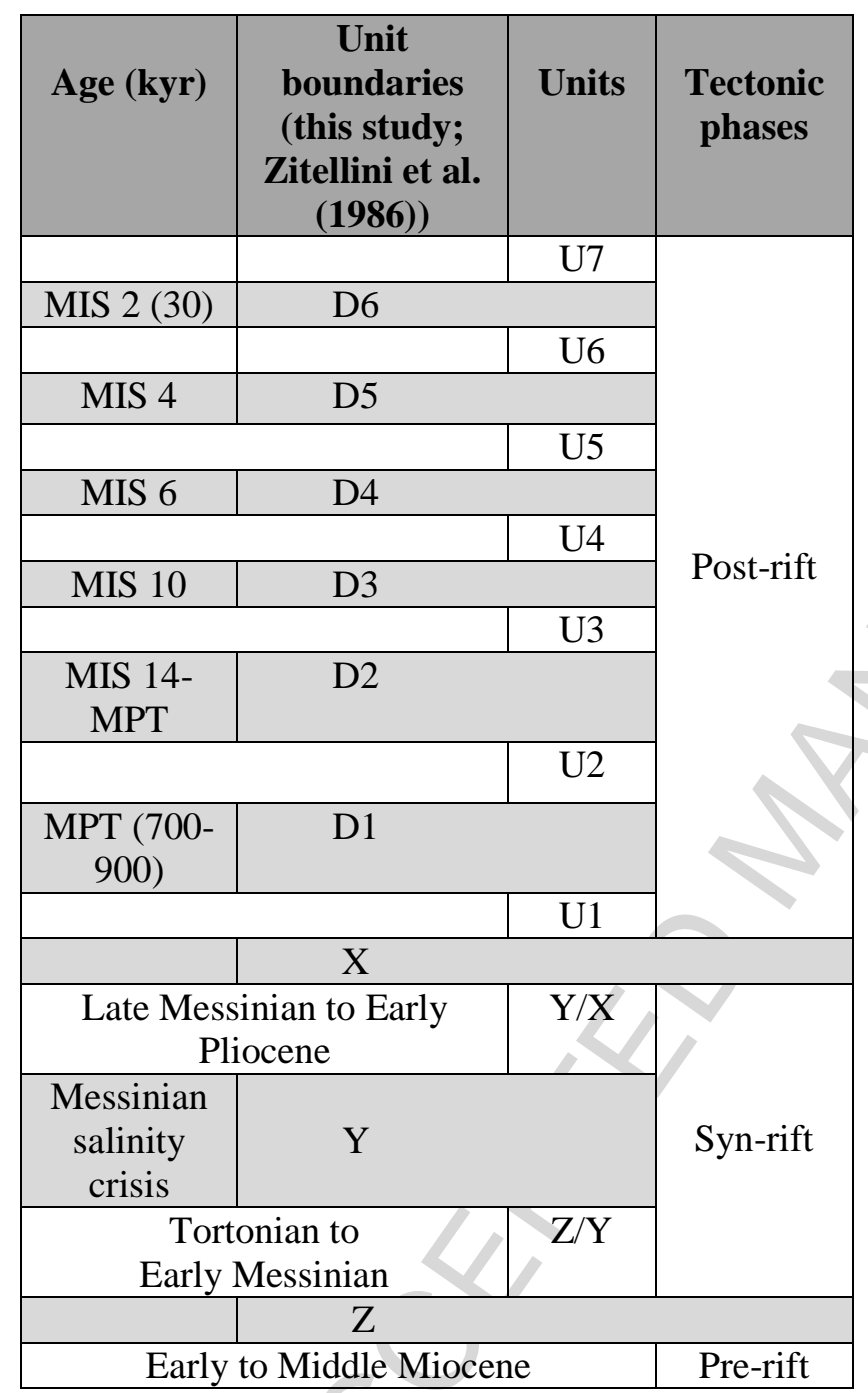

Table 2 